\title{
Sustained activation and tumor targeting of NKT cells using a CD1d-anti-HER2-scFv fusion protein induce antitumor effects in mice
}

\author{
Kathrin Stirnemann, ${ }^{1}$ Jackeline F. Romero, ${ }^{1}$ Lucia Baldi, ${ }^{2}$ Bruno Robert, ${ }^{3}$ Valérie Cesson, ${ }^{1,4}$ \\ Gurdyal S. Besra, ${ }^{5}$ Maurice Zauderer, ${ }^{6}$ Florian Wurm, ${ }^{2}$ Giampietro Corradin, ${ }^{1}$ \\ Jean-Pierre Mach, ${ }^{1} \mathrm{H}$. Robson MacDonald, ${ }^{4}$ and Alena Donda ${ }^{1}$
}

${ }^{1}$ Department of Biochemistry, University of Lausanne, Epalinges, Switzerland. 2Laboratory of Cellular Biotechnology,

Ecole Polytechnique Fédérale de Lausanne, Lausanne, Switzerland. ${ }^{3}$ INSERM U860, CRC Montpellier, University of Montpellier, CRLC Val d'Aurelle, Montpellier, France. ${ }^{4}$ Ludwig Institute for Cancer Research, Lausanne Branch, University of Lausanne, Lausanne, Switzerland. ${ }^{5}$ School of Biosciences, University of Birmingham, Birmingham, United Kingdom. ${ }^{6}$ Vaccinex Inc., Rochester, New York, USA.

\begin{abstract}
Invariant NKT (iNKT) cells are potent activators of DCs, NK cells, and T cells, and their antitumor activity has been well demonstrated. A single injection of the high-affinity CD1d ligand $\alpha$-galactosylceramide ( $\alpha$ GalCer) leads to short-lived iNKT cell activation followed, however, by long-term anergy, limiting its therapeutic use. In contrast, we demonstrated here that when $\alpha$ GalCer was loaded on a recombinant soluble CD1d molecule $(\alpha$ GalCer/sCD1d), repeated injections led to sustained iNKT and NK cell activation associated with IFN- $\gamma$ secretion as well as DC maturation in mice. Most importantly, when $\alpha$ GalCer/sCD1d was fused to a HER2specific scFv antibody fragment, potent inhibition of experimental lung metastasis and established s.c. tumors was obtained when systemic treatment was started 2-7 days after the injection of HER2-expressing B16 melanoma cells. In contrast, administration of free $\alpha \mathrm{GalCer}$ at this time had no effect. The antitumor activity of the CD1d-anti-HER2 fusion protein was associated with HER2-specific tumor localization and accumulation of iNKT, NK, and T cells at the tumor site. Targeting iNKT cells to the tumor site thus may activate a combined innate and adaptive immune response that may prove to be effective in cancer immunotherapy.
\end{abstract}

\section{Introduction}

Numerous studies, in animal models and in humans, have analyzed the potential role of the innate and adaptive immune systems in the control of tumor initiation and metastasis $(1,2)$. Major efforts are being made to manipulate these immune responses and to selectively promote their antitumor activities, such as the development of tumor vaccines and antibody-mediated tumor targeting (3, 4). Among the different actors of the immune system, a powerful antitumor activity has been attributed to invariant NKT (iNKT) cells, a subset of lymphoid cells that share characteristics of $\mathrm{T}$ and natural killer cells (5). Both in mice and humans, iNKT cells have an extremely restricted $\mathrm{T}$ cell receptor repertoire, consisting of an invariant $\alpha$ chain paired with a limited number of $\beta$ chains, and they coexpress NK cell markers, like the NK1.1 (CD161) molecule (5, 6). The semi-invariant TCR (semi-invTCR) on iNKT cells recognizes glycolipid antigens presented in the context of the monomorphic MHC class I-like molecule CD1d, and potential self and foreign natural lipid ligands have been identified $(7,8)$. When activated, iNKT cells immediately release large amounts of both proinflammatory TH1 cytokines, such as IFN $\gamma$ and TNF $\alpha$, and antiinflammatory TH2 cytokines $(9,10)$. This broad cytokine profile confers on iNKT cells a role in immunoregulation with the capacity to trans-

Nonstandard abbreviations used: $\alpha$ GalCer, $\alpha$-galactosylceramide; iNKT, invariant NKT; invTCR, invariant TCR; sCD1d, soluble $\beta_{2} \mathrm{~m}-\mathrm{CD} 1 \mathrm{~d}$; scFv, single-chain antibody Fv fragment.

Conflict of interest: The authors have declared that no conflict of interest exists. Citation for this article: J. Clin. Invest. 118:994-1005 (2008). doi:10.1172/JCI33249. activate cells of the innate and adaptive immune system. Regarding cancer development, iNKT cells seem to play either protective or exacerbating roles, depending on their kinetics of activation, phenotype, and tissue origin $(11,12)$. The antitumor activity of iNKT cells can be promoted by the use of the potent $\mathrm{CD} 1 \mathrm{~d}$-associated glycolipid ligand $\alpha$-galactosylceramide ( $\alpha$ GalCer), which binds with high affinity to the semi-invTCR on iNKT cells (13). Several studies in mice have demonstrated the early production of IFN $\gamma$ by $\alpha$ GalCer-activated iNKT cells, leading to the bystander activation of NK cells, which were shown to be the mediators of the inhibition of experimental lung and liver tumor metastases (14-16). Based on these promising experimental results, phase I clinical trials were conducted to test the efficacy of $\alpha \mathrm{GalCer}$ in cancer patients (17-19). However, the use of $\alpha$ GalCer in cancer therapy has been limited since its antitumor activity is only effective when administered shortly after tumor graft (13), and in addition, a single injection of $\alpha$ GalCer leads to a long-term anergy of iNKT cells $(20,21)$. Although the mechanism is not fully understood, it seems that the type of APC, rather than the dose of $\alpha \mathrm{GalCer}$, may be critical for the onset of anergy (21). So far, the most promising results have been obtained with the transfer, in mice and in humans, of $\alpha$ GalCerpulsed DCs instead of free $\alpha$ GalCer $(17,19-23)$. This approach showed a more prolonged iNKT cell activation as well as higher numbers of NK, $\mathrm{T}$, and $\mathrm{B}$ cells.

Here we report a noninvasive strategy to induce a sustained activation of iNKT cells and to promote their activation at the tumor site. We show that $\alpha$ GalCer-loaded recombinant soluble CD1d molecules (sCD1d) activate and keep iNKT cells responsive to 
A
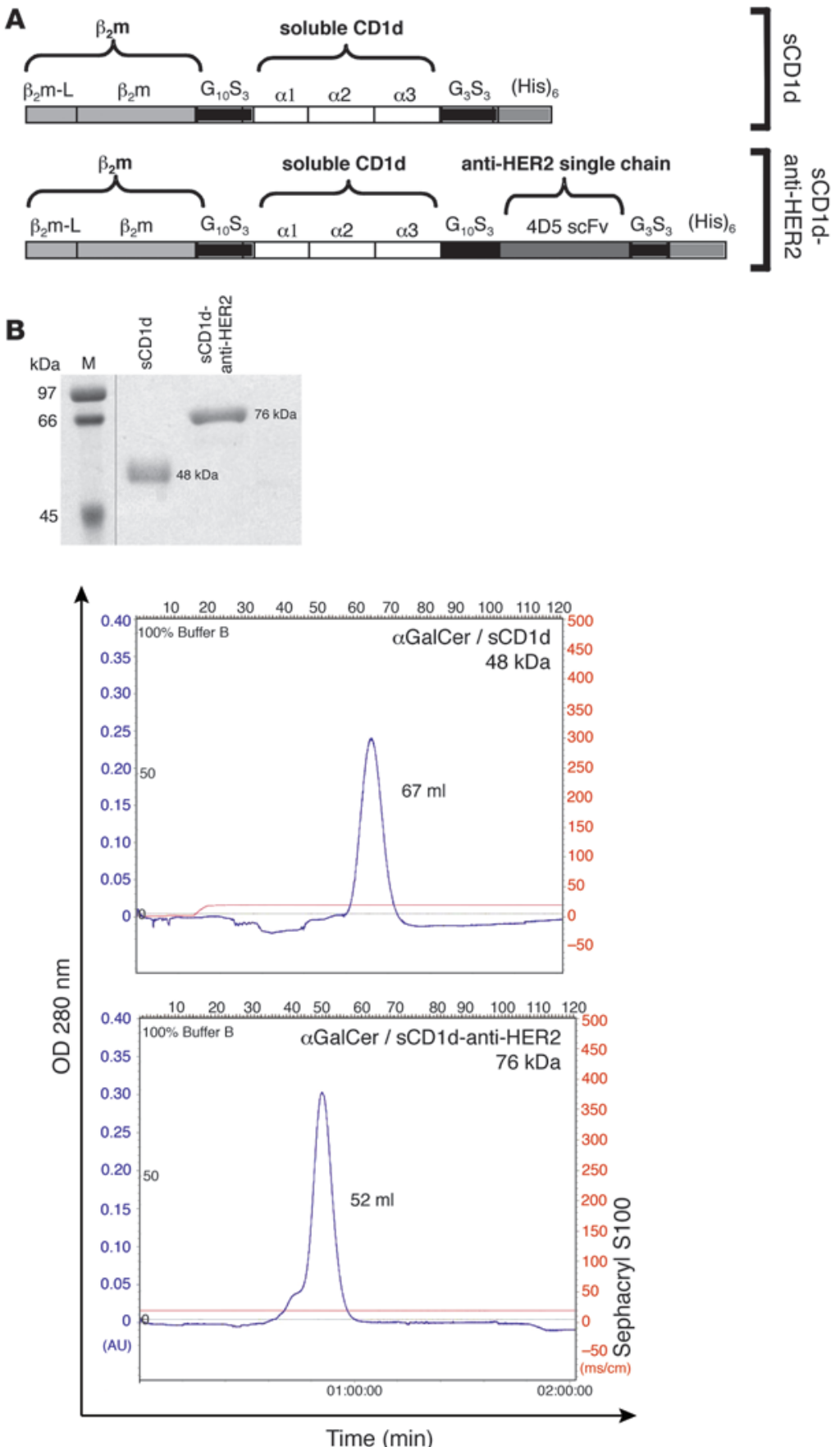

repeated stimulation. Furthermore, when the sCD1d is fused to an anti-HER2 single-chain antibody Fv fragment (scFv) antibody, systemic injections lead to a potent inhibition of HER2-expressing lung tumor colonies and established s.c. tumors, even upon delayed treatment. This antitumor activity is associated with an accumulation of iNKT, NK, and $\mathrm{T}$ cells at the tumor site, demonstrating that the targeting of CD1d to cancer cells is able to redirect effector cells from the innate and adaptive immune system to the tumor site.

\section{Results}

Construction, expression, and purification of recombinant mouse CD1d proteins with and without fusion to an anti-HER2 scFv antibody frag-

\section{Figure 1}

Design, production, and purification of recombinant CD1d molecules. (A) Design of the genetic fusions of mouse $\beta_{2} m$ with the SCD1d and the single chain of the murine anti-HER2 antibody 4D5 (4D5 scFv). DNA fragments were produced by PCR using primers, including sequences for flexible glycine-serine rich linkers $\left(\mathrm{G}_{10} \mathrm{~S}_{3}\right.$ and $\mathrm{G}_{3} \mathrm{~S}_{3}$ ). A His-tag $(\mathrm{His})_{6}$ was added at the $\mathrm{C}$-terminus for Ni-NTA purification. (B) SCD1d and SCD1d-antiHER2 fusion proteins after production in HEK293EBNA cells. Shown are $10 \%$ SDS-PAGE after purification of the proteins by Ni-NTA chromatography (upper panel) and FPLC Sephacryl S100 profiles after loading with $\alpha$ GalCer (lower panels). $\beta_{2} \mathrm{~m}-\mathrm{L}$, leader sequence of $\beta_{2} \mathrm{~m} ; \alpha 1-3$, extracellular domains of CD1d; M, molecular weight markers.

ment. We fused the mouse $\beta_{2}$-microglobulin $\left(\beta_{2} \mathrm{~m}\right)$ to the $\mathrm{N}$-terminus of mouse CD1d via a flexible Gly-Ser rich linker $\left(\mathrm{G}_{10} \mathrm{~S}_{3}\right)$, as described for human CD1d (24), to obtain fully assembled and secreted soluble $\beta_{2}$ m-CD1d complexes, referred to hereafter as $\mathrm{sCD} 1 \mathrm{~d}$. The $\alpha 3$ domain of $\mathrm{CD} 1 \mathrm{~d}$ was interrupted before the transmembrane region, and a small linker $\left(\mathrm{G}_{3} \mathrm{~S}_{3}\right)$ was inserted, followed by a His tag for purification $\left(\mathrm{His}_{6}\right.$ ) (Figure $1 \mathrm{~A}$ ). In addition, to confer the tumor localization properties of the $\alpha \mathrm{GalCer} /$ sCD1d, we fused the $\beta_{2} \mathrm{~m}-\mathrm{CD} 1 \mathrm{~d}$ molecule to an antitumor antibody fragment in view of our previous experience with tumor targeting of MHC class I coupled to different antitumor Fab' fragments $(25,26)$. To do so, a second $\left(\mathrm{G}_{10} \mathrm{~S}_{3}\right)$ linker was inserted at the C-terminus of CD1d before ligation to the cDNA of the anti-HER2 4D5 scFv (27), followed by the same small linker $\left(\mathrm{G}_{3} \mathrm{~S}_{3}\right)$ and His tag (Figure $\left.1 \mathrm{~A}\right)$. Transient transfection of HEK293 EBNA cells adapted to grow in suspension in serum-free medium (28) gave similar yields for both recombinant CD1d proteins, alone or fused to the anti-HER2 $\mathrm{scFv}$ (up to $10 \mathrm{mg} / \mathrm{l}$ supernatant). One-step purification of the supernatant on Ni-NTA resin was sufficient to reach purity as shown by a single band on SDS-PAGE, at 48 $\mathrm{kD}$ (sCD1d) and $76 \mathrm{kD}$ (sCD1d-anti-HER2), respectively (Figure 1B, upper panel). The CD1d molecules were loaded with a 3 -fold molar excess of $\alpha$ GalCer, and the unbound ligand was removed by size exclusion FPLC, during which the glycolipid micelles were eliminated in the void volume. A symmetric peak was eluted corresponding to the respective size of the CD1d molecules, alone or fused to the anti-HER2 scFv, demonstrating the monomeric and globular form of these single-chain fusion proteins and the absence of aggregates (Figure 1B, lower panels). The quality of the $\alpha \mathrm{GalCer} / \mathrm{sCD} 1 \mathrm{~d}$ and $\alpha \mathrm{GalCer} / \mathrm{sCD} 1 \mathrm{~d}$-anti-HER2 fusion proteins was checked by SDS-PAGE and FPLC over 1 month storage at $4^{\circ} \mathrm{C}$, and both molecules were stable. Recombinant proteins, loaded with $\alpha$ GalCer or alone, were checked for endotoxin contamination, which was found to be less than $0.5 \mathrm{EU} / \mu \mathrm{g}$ protein corresponding to less than 0.04 ng endotoxin.

HER2 binding and biological activity of recombinant CD1d fusion proteins. The sCD1d-anti-HER2 fusion protein specifically bound to 

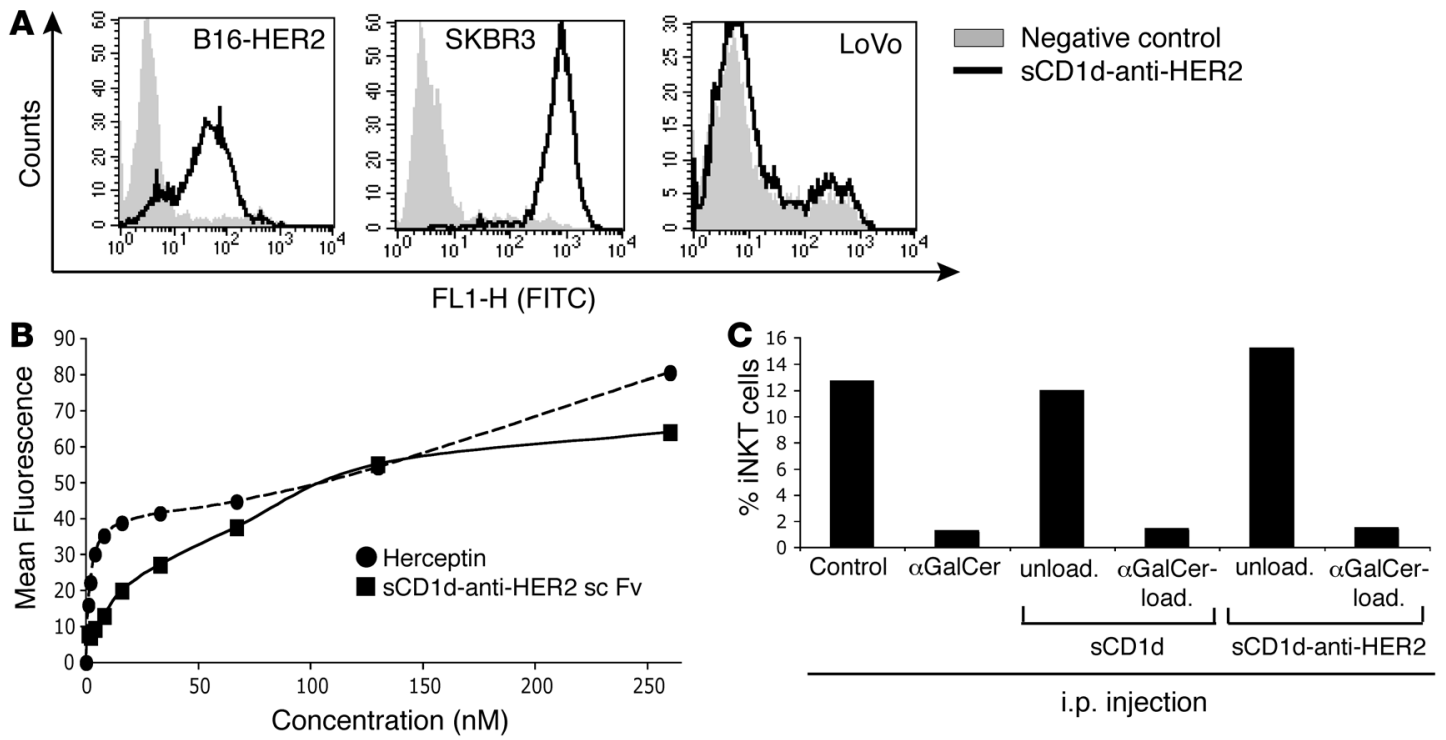

i.p. injection

\section{Figure 2}

Binding and biological activity of recombinant CD1d molecules. (A) Binding of the SCD1d-anti-HER2 protein to HER2-expressing target cells, and recognition by FITC-labeled anti-CD1d. HER2-positive target cells (B16-HER2 and SKBR3) are recognized while HER2-negative LoVo cells are not. (B) Titration of the binding of the sCD1d-anti-HER2 scFv protein or the full anti-HER2 antibody Herceptin to B16-HER2 cells. Detection was performed using anti-CD1d-FITC and anti-human IgG FITC, respectively. (C) In vivo bioactivity of $\alpha$ GalCer-loaded sCD1d and sCD1d-anti-HER2, shown by the transient disappearance of liver iNKT cells secondary to the activation-induced downmodulation of the invariant T cell receptor. Liver lymphocytes were analyzed for numbers of iNKT cells 20 hours after i.p. injection of PBS (control) and $5 \mu \mathrm{g} \alpha \mathrm{GalCer}$, $20 \mu \mathrm{g}$ unloaded or $\alpha$ GalCer-loaded sCD1d, $40 \mu \mathrm{g}$ unloaded or $\alpha$ GalCer-loaded SCD1d-anti-HER2 fusion. Detection by FACS using PE-labeled $\alpha \mathrm{GalCer/CD1d-tetramer} \mathrm{and} \mathrm{FITC-labeled} \mathrm{anti-CD3.} \mathrm{Results} \mathrm{are} \mathrm{expressed} \mathrm{in} \mathrm{percent} \mathrm{of} \mathrm{iNKT} \mathrm{cells} \mathrm{from} \mathrm{total} \mathrm{liver} \mathrm{lymphocytes.}$

HER2-expressing tumor cell lines, namely the murine B16 melanoma cell line stably transfected with the human HER2 antigen and the naturally HER2-expressing human breast carcinoma cell line SK-BR-3, while no binding was observed on the HER2-negative human colon carcinoma cell line LoVo (Figure 2A). The binding was revealed with an anti-CD1d antibody, demonstrating that both the CD1d and the anti-HER2 parts were properly folded and functional. Titration of the binding of the SCD1d-anti-HER2 fusion protein to B16-HER2 melanoma cells was compared with that obtained with the intact anti-HER2 $\mathrm{mAb}$ Herceptin (Figure 2B). The molarity of the CD1d fusion protein required to reach saturation was about 5 times higher than that needed for the intact anti-HER $2 \mathrm{mAb}$ (150 and $30 \mathrm{nM}$, respectively). This lower binding affinity is explained by the fact that the anti-HER2 scFv has a single antigen binding site, which is fused via a spacer to the C-terminus of sCD1d, as compared with a bivalent intact antibody. The $\alpha \mathrm{GalCer} / \mathrm{sCD} 1 \mathrm{~d}$ and $\alpha \mathrm{GalCer} / \mathrm{sCD} 1 \mathrm{~d}$-anti-HER2 fusion proteins were tested for their in vivo capacity to transiently downregulate the iNKT TCR, as has been shown for $\alpha$ GalCer alone (29). Twenty hours after i.p. injection, the semi-invTCR on the liver NKT population, stained with CD1d tetramer and anti-CD3 mAb, was indeed downregulated to the same extent in mice treated with equimolar amounts of $\alpha \mathrm{GalCer}-\mathrm{loaded}$ recombinant CD1d proteins or $\alpha \mathrm{GalCer}$ alone. In contrast, injection of unloaded CD1d complexes had no effect on the frequency of liver iNKT cells (Figure 2C).

The $\alpha$ GalCer/sCD1d-anti-HER2 fusion protein bound on tumor cells prevents the development of lung tumor nodules. The model of experimental lung metastasis induced by the i.v. injection of the B16 melanoma cell line $(15,16,30)$ was used to test the antitumor activity of the recombinant CD1d complexes. To express the results, we devel- oped a method that takes into account both the size and number of tumor nodules, as illustrated by 2 lung pictures, in which the degree of metastasis was analyzed either by the number of nodules or by the mean area invaded by melanin (Figure 3A; see Methods). The latter quantification of metastases was much more accurate since the size of nodules was often heterogenous or their numbers were sometimes so elevated that counting became impossible.

As a first approach to test the antitumor activity of the $\alpha \mathrm{GalCer} /$ sCD1d alone or fused to the anti-HER2 scFv, B16 melanoma cells, wild type or stably transfected with the human HER2 antigen were pre-incubated with equimolar amounts of either $\alpha \mathrm{GalCer}$ alone or the $\alpha \mathrm{GalCer} / \mathrm{sCD} 1 \mathrm{~d}$-anti-HER2 fusion or the intact anti-HER2 $\mathrm{mAb}$, before being injected i.v. into naive mice. As already reported (13), coinjection of $\alpha$ GalCer with the tumor cells completely inhibited tumor development, whether or not the tumor cells expressed the HER2 antigen (Figure 3, B and C). Since B16 melanoma cells do not express CD1d, the free $\alpha$ GalCer coinjected with the tumor cells was likely presented by in vivo encountered CD1d-expressing APCs. In contrast, the $\alpha$ GalCer/sCD1d-anti-HER2 fusion inhibited tumor growth only when HER2 was expressed on the tumor cells (Figure 3, B and C). This effect was retained after several washings of the tumor cells, indicating that the antitumor effect was due to the HER2-bound fusion protein. However, the intact antiHER2 mAb did not inhibit lung metastases of B16-HER2 tumor cells (Figure 3B), indicating that the antitumor effect of the bound fusion protein was iNKT cell mediated. In addition, these results demonstrate that the HER2-dependent antitumor activity was due to the $\alpha \mathrm{GalCer} / \mathrm{sCD} 1 \mathrm{~d}$-anti-HER2 per se and not to the in vivo release of $\alpha$ GalCer, since the $\alpha$ GalCer/sCD1d-anti-HER 2 did not inhibit the development of tumor nodules derived from wild-type 
A

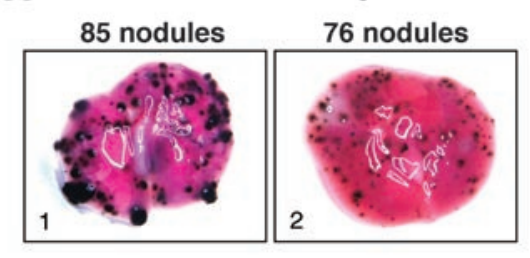

$\%$ Surface covered with metastases:
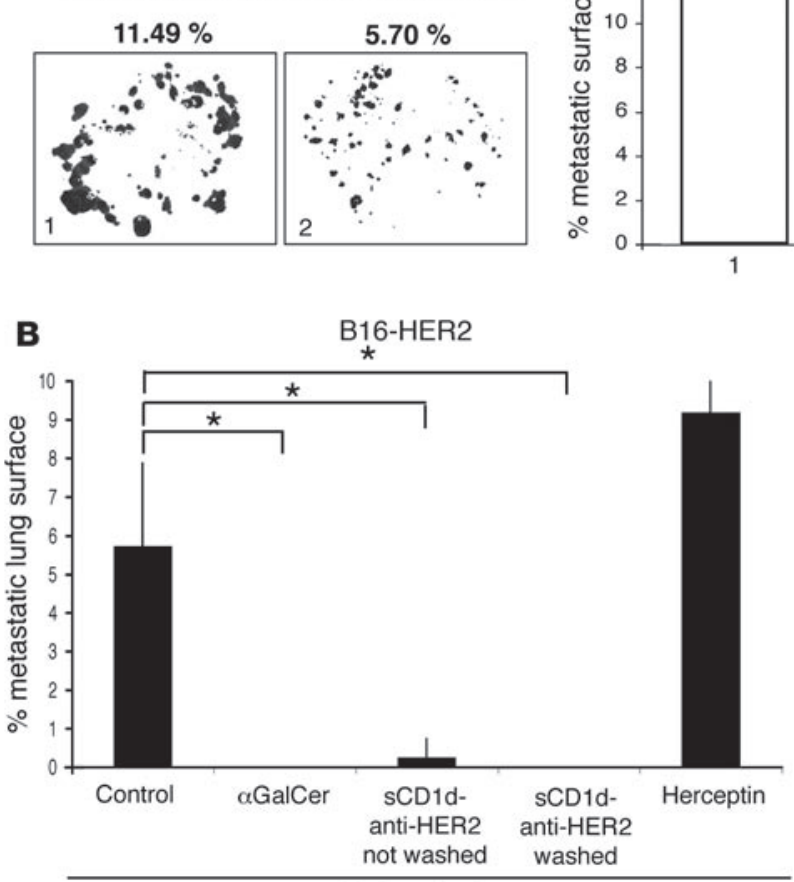

Preincubation
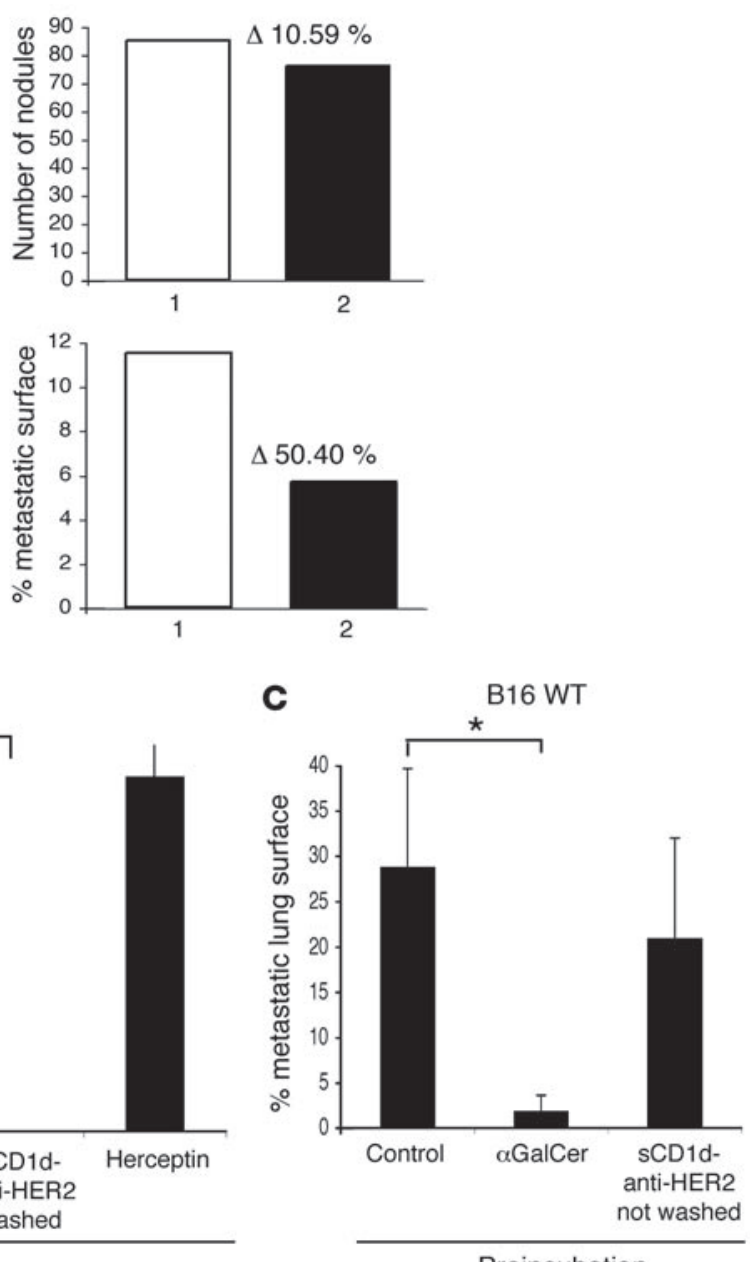

Preincubation

Figure 3

In vivo antitumor activity and HER2 dependency in a precoating experiment. (A) Comparison of 2 different read-out methods for counting lung tumor colonies induced by the i.v. injection of B16 F10 melanoma cells in 2 representative mice ( 1 and 2): counting of nodules (upper panels) versus the use of ImageJ k-means clustering algorithm program to integrate the black surface of melanin-loaded nodules and to express the result as percent of black surface over total lung surface (lower panels). Original magnification, $\times 6.3$. (B and C) Precoating experiment. B16-HER2 (B) and B16 wt cells (C) were precoated for $1 \mathrm{~h}$ with equimolar amounts of $\alpha$ GalCer $(0.4 \mu \mathrm{g} / \mathrm{ml})$, $\alpha$ GalCer/sCD1d-anti-HER2 fusion $(40 \mu \mathrm{g} / \mathrm{ml})$, or Herceptin $(10 \mu \mathrm{g} / \mathrm{ml})$. With or without a previous wash, cells were injected i.v. in C57BL/6 mice. Lung metastases were analyzed 3 weeks after graft as described in A. Results are expressed as percent of black surface of total lung surface and represent the mean \pm SD of 5 mice per group of 3 independent experiments. ${ }^{*} P<0.005$ compared with PBS control.

B16 melanoma cells (Figure 3C). In these preincubation settings, the antitumor activity of the sCD1d-anti-HER2 protein was not superior to the already optimal effect of free $\alpha$ GalCer coinjected with tumor cells. However, the selective effect on HER2-expressing tumor cells provided the first evidence that the sCD1d-anti-HER2 fusion protein targeted on HER2-expressing cancer cells can redirect iNKT cells to the tumor site.

Delayed systemic treatment with the $\alpha \mathrm{GalCer} / \mathrm{sCD} 1 \mathrm{~d}$-anti-HER2 leads to a significant inbibition of lung metastases as well as of established s.c. tumors. In view of the results obtained in precoating experiments, we tested the $\alpha \mathrm{GalCer} / \mathrm{sCD} 1 \mathrm{~d}$-anti-HER2 fusion protein in systemic treatments started at different time points after the injection of B16-HER2 melanoma cells. Free $\alpha$ GalCer, if injected 2 or 6 graft of B16-HER2 cells, when tumors were all palpable (50-100 $\mathrm{mm}^{3}$ ) (Figure 4C). As in the model of lung metastasis, the tumor size at the end of the experiment was on average $60 \%$ smaller in the mice treated with the $\alpha$ GalCer/sCD1d-anti-HER2 fusion protein, as compared with untreated or free $\alpha$ GalCer-treated mice, which all showed fast tumor growth. The nontumor-targeted $\alpha \mathrm{GalCer} / \mathrm{sCD} 1 \mathrm{~d}$ protein showed a slight effect of tumor growth inhibition, which was however, not statistically significant when compared with untreated and free $\alpha$ GalCer-treated mice. The intact murine anti-HER2 mAb 4D5 did not inhibit the growth of B16-HER2 tumor cells, nor did the coinjection of anti-HER $2 \mathrm{mAb}$ with $\alpha \mathrm{GalCer} / \mathrm{sCD} 1 \mathrm{~d}$ (Figure $4 \mathrm{C}$ ). These results exclude the possibility that the antitumor effect seen in both 
A

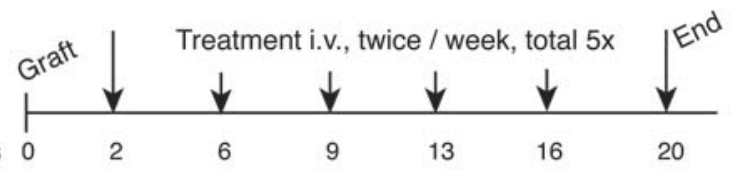

Days

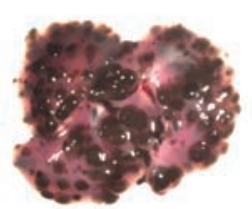

Control

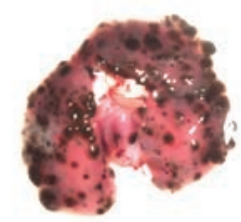

$\alpha$ GalCer

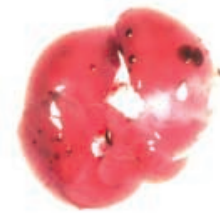

sCD1d-anti-HER2

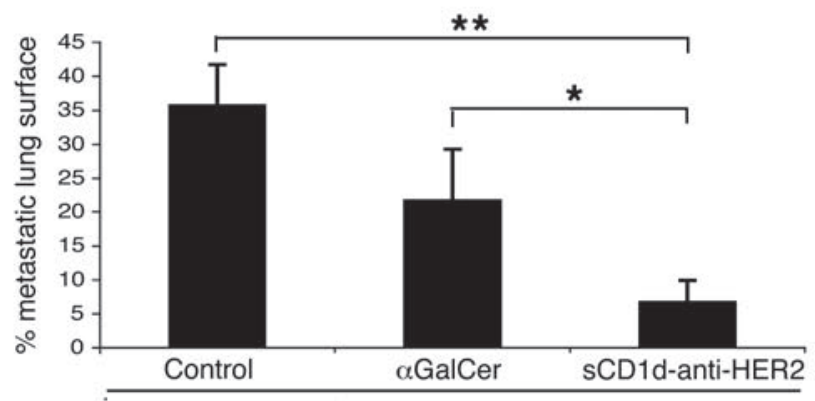

Systemic treatment

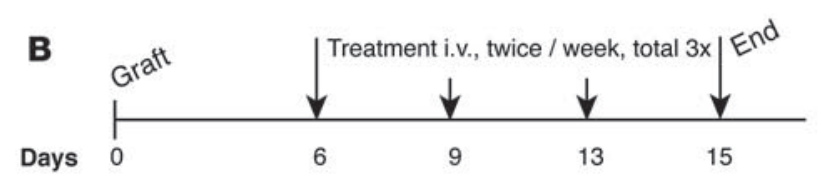

$\star \star \star$

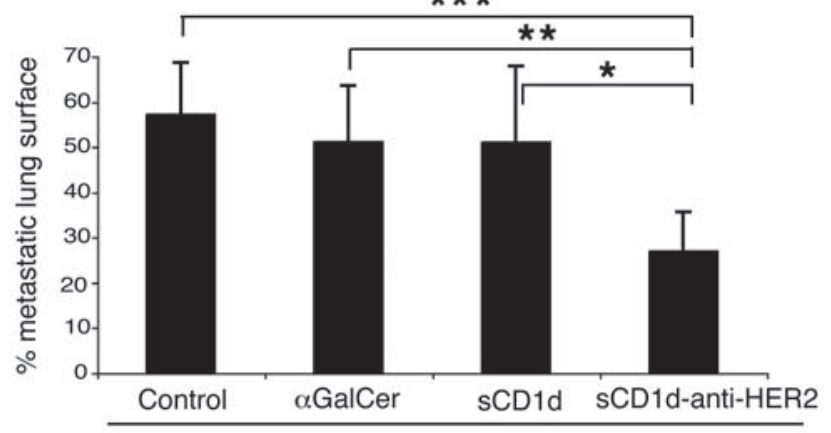

Systemic treatment

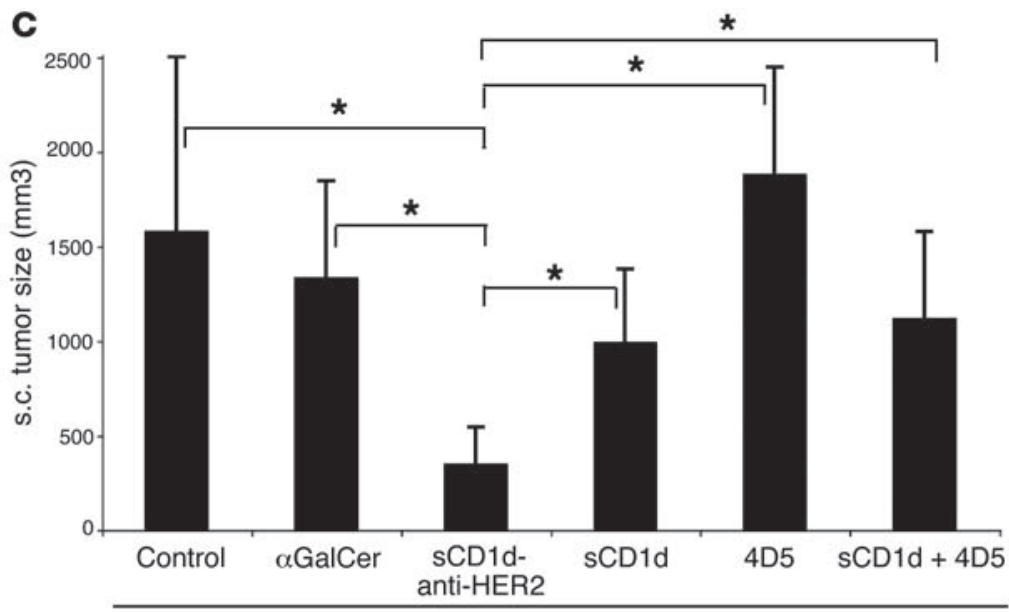

Systemic treatment
Figure 4

In vivo antitumor activity in systemic treatments. (A) Mice were grafted i.v. with 700,000 B16-HER2 cells and i.v. treatment was started 48 hours later. Mice were injected 5 times i.v. every 3-4 days (arrows) with either PBS (control), equimolar amounts of $\alpha$ GalCer $(0.4 \mu \mathrm{g})$, or $\alpha \mathrm{GalCer}$ loaded sCD1d-anti-HER2 fusion (40 $\mu \mathrm{g})$. Mice were analyzed after 3 weeks and results are shown as pictures of tumors-invaded lungs ( 1 representative lung per group; original magnification, $\times 6.3$ ), and in the graph expressed as percent of lung surface invaded by melanin-loaded tumor nodules. Results represent the mean \pm SD of 5 mice per group of 2 independent experiments. ${ }^{* \star} P<0.005$ versus control; * $P<0.04$ versus $\alpha$ GalCer. (B) Mice were grafted as above, and treatment was started 6 days after with the same protocol as in A including treatment with SCD1d $(25 \mu \mathrm{g})$. Lung nodules were analyzed after 2 weeks. Results represent the mean \pm SD of 6 mice per group of 2 independent experiments. ${ }^{* *} P=0.0006$ versus control; ${ }^{* *} P<0.004$ versus $\alpha$ GalCer; ${ }^{*} P<0.02$ versus sCD1d. (C) Mice were grafted s.c. on the right flank with 700,000 B16HER2 cells and i.v. treatment as in $\mathbf{B}$ was started 7 days later, when all tumors were palpable. Additional groups treated with 4D5 alone $(80 \mu \mathrm{g})$ or the combination of $4 \mathrm{D} 5+$ sCD1d $(80+25 \mu \mathrm{g})$ were included. Results expressed as the mean tumor size in $\mathrm{mm}^{3} \pm \mathrm{SD}$ measured at the end of the treatment (day 18) of 4 mice per group. Statistical significance of $\alpha \mathrm{GalCer} / \mathrm{sCD} 1 \mathrm{~d}$-anti-HER2treated group was of ${ }^{*} P<0.05$ versus all other groups.

tumor models might result from an adjuvant activity of sCD1d on the otherwise undetectable effect of the anti-HER 2 antibody. This was confirmed by the fact that the anti-HER2 antibodies detected at the end of the experiment in the sera of mice grafted with the B16-HER2 cells (data not shown) did not participate in the antitumor effect, as shown by the fast tumor development in all the mice, except when treated with the $\alpha$ GalCer/sCD1d-anti-HER2 fusion protein (Figure 4). Altogether, the marked inhibition of experimental lung metastasis and established s.c. tumors obtained exclusively with the $\alpha \mathrm{GalCer} /$ $\mathrm{sCD} 1 \mathrm{~d}$-anti-HER2 fusion protein suggests that activated iNKT cells can be redirected to the tumor site and remain responsive to repeated injections of recombinant $\alpha$ GalCer-loaded $s C D 1 d$ complexes, in contrast to the anergy induced by repeated stimulation with free $\alpha$ GalCer.

$i N K T$ cells are required for the antitumor effect of the $\alpha G$ alCer/sCD1d-anti-HER2 fusion protein. To prove the essential role of activated iNKT cells in the antitumor effect of the $\alpha \mathrm{GalCer} / \mathrm{sCD} 1 \mathrm{~d}$-anti-HER2 fusion protein, a systemic treatment was performed in $\mathrm{CD} 1 \mathrm{~d}^{-/-}$mice after the s.c. injection of B16-HER2 tumor cells (Figure 5A). Even with an early treatment started 2 days after tumor graft, the $\alpha$ GalCer/sCD1danti-HER2 fusion protein was unable to block tumor growth in $\mathrm{CD} 1 \mathrm{~d}^{-/}$mice, while efficient inhibition occurred in wild-type treated mice. These results demonstrate the essential role of iNKT cells in mediating the antitumor effect of the recombinant $\alpha \mathrm{GalCer} /$ sCD1d-anti-HER2 fusion protein. 
A

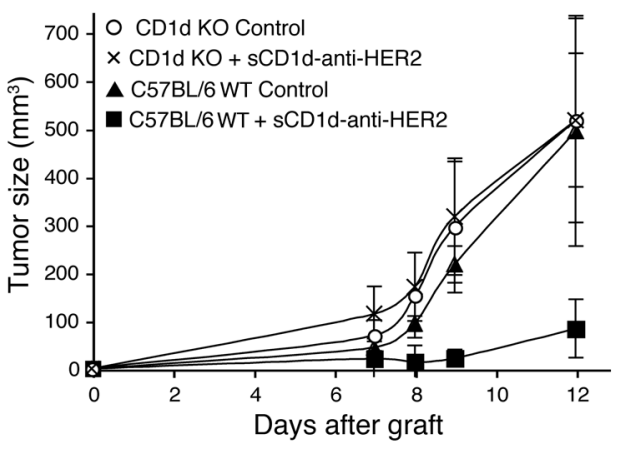

B

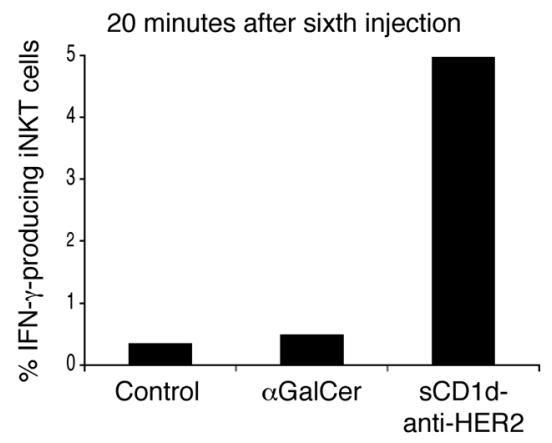

C

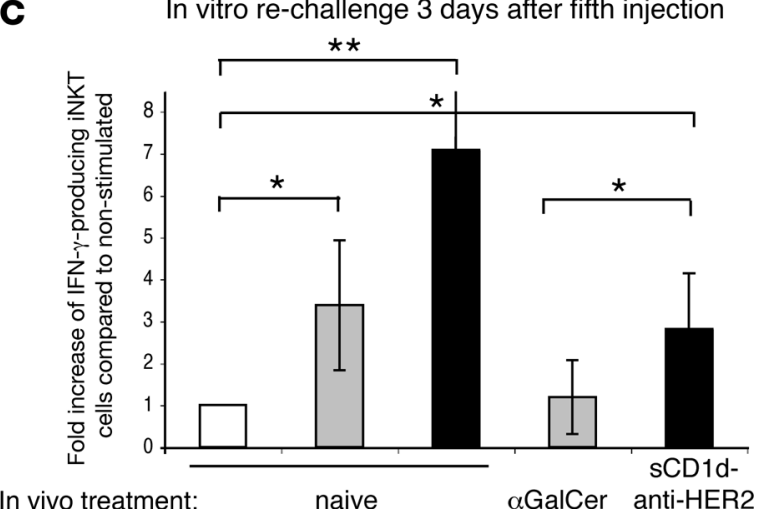

iNKT cells remain responsive to repeated injections of recombinant $\alpha G$ alCer $/ s C D 1 d$ proteins, as shown by sustained IFN $\gamma$ production. In order to investigate the mechanism of action of the $\alpha \mathrm{GalCer} /$ sCD1d-anti-HER2 fusion protein, we tested the cytokine profile of iNKT cells either shortly after an i.v. injection or after in vitro restimulation following a systemic treatment. Interestingly, the activated iNKT cells exhibited a bias towards a TH1 cytokine profile. When liver iNKT cells were analyzed 20 minutes following the sixth injection of $\alpha \mathrm{GalCer} / \mathrm{sCD} 1 \mathrm{~d}$-anti-HER2 fusion protein, IFN $\gamma$ could be detected in about $5 \%$ of NK1.1 $1^{+} \mathrm{CD}^{+}$double-positive cells, while no significant IFN $\gamma$ was produced in mice treated with equimolar amounts of $\alpha \mathrm{GalCer}$ (Figure 5B). In addition, liver iNKT cells from $\alpha$ GalCer/sCD1d-anti-HER2-treated mice remained responsive to in vitro rechallenge with the same stimulus, performed 3 days after the fifth in vivo injection, as shown by a significant fold increase in IFN $\gamma$-positive iNKT cells (Figure 5C). In contrast, liver iNKT cells from $\alpha$ GalCer-treated mice remained unresponsive to $\alpha$ GalCer restimulation, while iNKT cells from naive mice were responsive to both stimuli (Figure 5B). In all experiments, no significant amount of IL-4 was detected follow-

\section{Figure 5}

iNKT cells are required for the antitumor effect and are characterized by a sustained activation with $\mathrm{TH} 1$ bias. (A) The antitumor activity is lost in the absence of iNKT cells. C57BL/6 or CD1d $\mathrm{d}^{-/-}$mice were grafted on the left flank with $700,000 \mathrm{~B} 16-\mathrm{HER} 2$ cells, and systemic treatment with the $\alpha$ GalCer/sCD1d-anti-HER2 was started 2 days later $(40 \mu \mathrm{g} /$ i.v. injection every 3 days). For each mouse strain, a group was left untreated. Results represent the kinetic of s.c. tumor growth (in $\mathrm{mm}^{3}$ ) as the mean \pm SD of 4 mice per group. (B) Ex vivo IFN $\gamma$ production by liver iNKT cells after several injections of $\alpha \mathrm{GalCer} / \mathrm{sCD} 1 \mathrm{~d}-$ anti-HER2 fusion. Liver lymphocytes were isolated 20 minutes after the sixth injection of PBS (control), $\alpha$ GalCer, or sCD1d-anti-HER2 protein, and cultured for $1 \mathrm{~h}$. Cells were stained with anti-NK1.1-PE and anti-CD3FITC, and intracellularly with anti-IFN $\gamma-A P C$. Graph shows percent of IFN $\gamma$-producing iNKT (gated on NK1.1+ CD3+ cells). (C) Sustained IFN $\gamma$ production by liver iNKT cells after several i.v. injections as indicated, followed by in vitro rechallenge with the same stimuli as in vivo. Liver lymphocytes were isolated 3 days after the fifth injection and restimulated in vitro for 6 hours. Naive mice were tested with $\alpha \mathrm{GalCer}$ or $\alpha \mathrm{GalCer} / \mathrm{sCD} 1 \mathrm{~d}-$ anti-HER2. Cells were stained as described in $B$ and results are expressed as fold increase of IFN $\gamma$-producing liver iNKT cells compared with the nonstimulated iNKT fraction derived from the same mouse. White bar, no in vitro stimulation; gray bar, in vitro $\alpha$ GalCer; black bar, in vitro SCD1d-anti-HER2. Results show the mean \pm SD of 3 different experiments. ${ }^{*} P<0.03$, ${ }^{* *} P<0.005$.

ing stimulation with the $\alpha \mathrm{GalCer} / \mathrm{sCD} 1 \mathrm{~d}$-anti-HER2 protein or free $\alpha$ GalCer (data not shown).

$i N K T$ cells activated by recombinant $\alpha \mathrm{GalCer} / s \mathrm{CD} 1 \mathrm{~d}$ proteins retain their capacity to transactivate NK cells and promote DC maturation. iNKT cells activated by $\alpha$ GalCer-loaded recombinant CD1d molecule also retained their known capacity to transactivate NK cells $(31,32)$. Higher numbers of IFN $\gamma$-producing NK cells were indeed detected in the liver of the same mice as in Figure 5, analyzed 20 minutes following the sixth i.v. injection of $\alpha \mathrm{GalCer} / \mathrm{sCD} 1 \mathrm{~d}-$ anti-HER2 protein (Figure 6A). Similarly, in vitro restimulation of liver iNKT cells with $\alpha$ GalCer/sCD1d-anti-HER2 fusion protein showed a parallel IFN $\gamma$ production in the population of NK cells (Figure 6B). In contrast, in $\alpha$ GalCer-treated mice, the same population of NK cells did not produce significant IFN $\gamma$ after restimulation in vivo or in vitro with $\alpha$ GalCer (Figure 6, A and B). In view of these results, the importance of transactivated NK cells for the antitumor activity of the $\alpha \mathrm{GalCer} / \mathrm{sCD} 1 \mathrm{~d}$-anti-HER2 fusion protein was evaluated. NK cell depletion by multiple injections of anti-asialo-GM1 antibodies was done in conjunction with the systemic treatment of established s.c. tumors (Figure $6 \mathrm{C})$. The $\alpha \mathrm{GalCer} / \mathrm{sCD} 1 \mathrm{~d}-\mathrm{anti}-\mathrm{HER} 2$ protein lost more than half of its capacity to inhibit tumor growth in mice depleted of NK cells, and the kinetics of tumor development were not significantly different from the untreated group. These results confirm the importance of NK cells in mediating the antitumor activity of activated iNKT cells, as already reported in other experimental settings $(14,15,23)$.

iNKT cells have also been attributed with the ability to modulate the adaptive immune response by promoting DC maturation (33-35). We investigated whether these modulating properties of iNKT cells were retained upon their activation with recombinant $\alpha$ GalCer/sCD1d proteins. Markers for mature DCs were analyzed in spleens isolated from mice 16 hours after the third i.v. injection of either PBS, $\alpha \mathrm{GalCer}$, or $\alpha \mathrm{GalCer} / \mathrm{sCD} 1 \mathrm{~d}$ protein. FACS analysis on sorted and gated CD11 $c^{+}$DC showed that iNKT cells, repeat- 
A

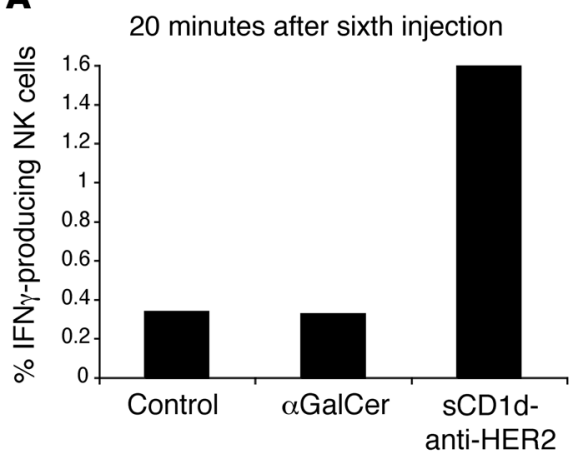

B

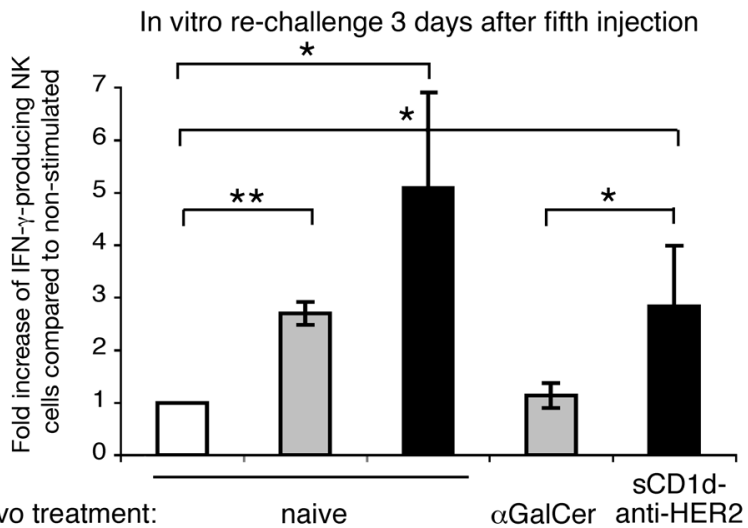

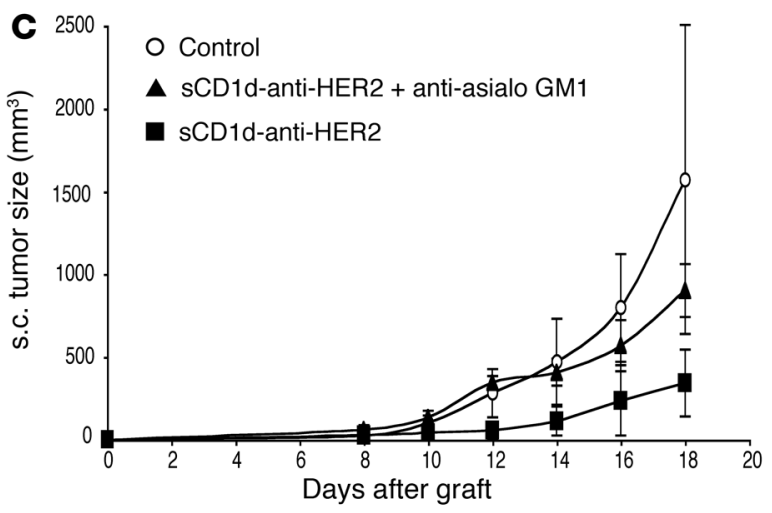

D
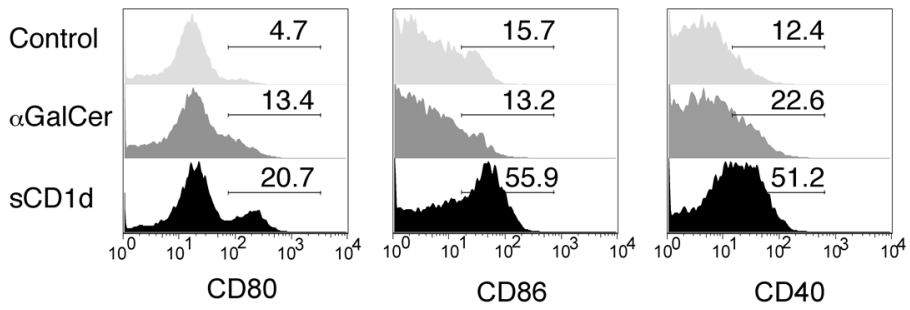

Figure 6

Activated iNKT cells retain their capacity to transactivate NK cells and promote DC maturation. Production of IFN $\gamma$ by NK cells in the same mice analyzed in Figure 5, ex vivo 20 min after an i.v. injection (A) or after in vitro rechallenge (B). NK population was gated on NK1.1 single positive cells. (A) Results are expressed as percent of IFN $\gamma$-producing NK cells. (B) Same legend as in Figure 5B. ${ }^{*} P<0.05$; ${ }^{* *} P<0.0006$. (C) The antitumor activity is in great part lost after NK cell depletion. Three groups of mice were grafted s.c. with 700,000 B16-HER2 cells, and 2 groups were treated with the $\alpha \mathrm{GalCer} / \mathrm{sCD} 1 \mathrm{~d}-$ anti-HER2 fusion 7 days later when tumors were palpable. For NK cell depletion, 1 of these groups was repeatedly i.p. injected with anti-asialo-GM1 antibodies during the whole treatment with the $\alpha$ GalCer/sCD1d-anti-HER2 protein. Results represent the kinetic of s.c. tumor growth (in $\mathrm{mm}^{3}$ ) as the mean \pm SD of 4 mice per group. (D) Induction of DC maturation by $\alpha \mathrm{GalCer} / \mathrm{sCD} 1 \mathrm{~d}$ activated iNKT cells. Splenocytes were isolated 16 hours after the third i.v. injection of PBS (control), equimolar amounts of $\alpha \mathrm{GalCer}(0.4 \mu \mathrm{g}$ ), or $\alpha$ GalCer-loaded SCD1d $(25 \mu \mathrm{g})$. DCs were sorted with anti-CD11c magnetic beads and stained with anti-CD11c-FITC and either biotinylated with anti-CD80, anti-CD86, or anti-CD40 antibodies followed by Streptavidin-PE. Results show the 3 activation markers on gated CD11C-positive cells, and numbers indicate the percent of cells with upregulated marker.

edly activated by the $\alpha \mathrm{GalCer} / \mathrm{sCD} 1 \mathrm{~d}$ protein, promoted the maturation of DCs, as shown by the upregulation of CD80, CD86, and CD40 in a large proportion of DCs (Figure 6D). In contrast, after 3 injections, free $\alpha$ GalCer had only a weak effect on all DC activation markers, indicating that anergic iNKT cells were no more able to promote DC maturation. These results demonstrate that iNKT cells, repeatedly activated by recombinant $\alpha$ GalCer-loaded CD1d molecules, keep their capacity to promote DC maturation.

These results were obtained with liver and spleen lymphocytes, indicating that the iNKT and NK cell activation as well as DC maturation were induced by recombinant SCD1d molecules independently of HER2-binding. However, potent antitumor effect occurred only when these effector cells were redirected to HER2expressing lung and s.c. tumors by the targeting of the $\alpha \mathrm{GalCer} /$ sCD1d-anti-HER2 fusion protein.

Repeated injections of recombinant $\alpha$ GalCer $/ s C D 1 d$ proteins leads to a bigher frequency of iNKT cells. Systemic treatment with either the $\alpha$ GalCer/sCD1d-anti-HER2 fusion protein or the non-HER2-targeted sCD1d led to an increased frequency of iNKT cells in the periphery, while $\alpha$ GalCer treatment showed undetectable levels as in untreated mice (Figure 7). Whether this increased frequency correlated with active proliferation needed further investigation. Moreover, the systemic activation of iNKT cells by $\alpha$ GalCer-loaded sCD1d molecules did not explain the exclusive antitumor activity of the HER2-targeted $\alpha \mathrm{GalCer} / \mathrm{sCD} 1 \mathrm{~d}$ fusion protein, suggesting that binding of sCD1d to HER2-positive tumor cells was able to redirect and activate iNKT cells at the tumor site.

Systemic injection of the $\alpha$ GalCer/sCD1d-anti-HER2 protein leads to an accumulation of $i N K T, N K$, and T cells at the tumor site and to a HER2-specific tumor localization of the fusion protein. When cell proliferation and tissue localization were tested by BrdU incorporation, a preferential specific accumulation of BrdU-positive iNKT cells was detected in the tumor-invaded lungs of mice treated with the HER2-targeted sCD1d. A 5-fold increase was obtained when HER2-targeted sCD1d mice were compared with untreated mice and a more than 2-fold increase was obtained when they were compared with nontargeted $\alpha$ GalCer/sCD1d (Figure $8, \mathrm{~A}$ and B). Importantly, a 7- and 8-fold enrichment in BrdU-positive NK cells 

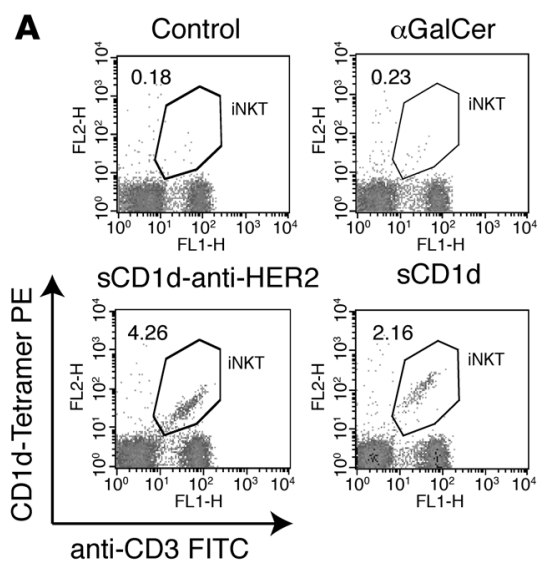

B

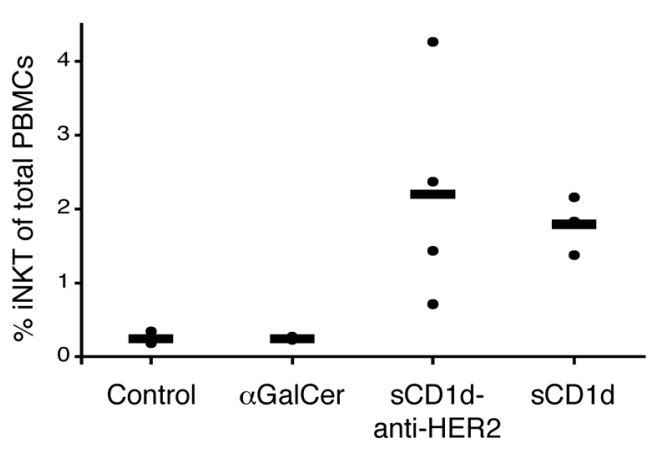

Figure 7

Recombinant $\alpha$ GalCer/sCD1d proteins induce a higher frequency of iNKT cells. (A) iNKT cell expansion after several injections of recombinant $\alpha$ GalCer-loaded CD1d molecules. Mice from systemic treatments (Figure 4) were bled after the third injection, and iNKT cells were stained in PBMCs using CD1d-tetramer-PE and anti-CD3-FITC. Dot plots of 1 representative mouse per group are shown, and numbers indicate percent of iNKT cells in total PBMCs. (B) Percent of iNKT cells in 4 individual mice per group including mean value.

and conventional $\mathrm{T}$ cells, respectively, was seen in the tumor-bearing lungs of $\alpha \mathrm{GalCer} / \mathrm{sCD} 1 \mathrm{~d}$-anti-HER 2 treated mice, while in the same tissue the nontargeted SCD1d led to a 4- and 2-fold increase, respectively (Figure 8, A and B). In contrast, in PBMC and spleen, there was even a slightly weaker accumulation of BrdU-positive iNKT, NK, and T cells in mice treated with the $\alpha$ GalCer/sCD1danti-HER2 protein as compared with $\alpha$ GalCer/sCD1d (Figure $8 \mathrm{~B}$ ). Altogether, these data demonstrate first that the $\alpha$ GalCer-loaded sCD1d molecules induced the in vivo proliferation of iNKT cells, while free $\alpha$ GalCer was not efficient; second, that this iNKT cell proliferation was associated with a concomitant expansion of NK cells and T cells; and third, that only the HER2-targeted $\alpha$ GalCer/ sCD1d protein was able to efficiently redirect iNKT, NK, and conventional $\mathrm{T}$ cells to the tissue invaded by HER2-positive tumors, explaining the exclusive antitumor activity of this fusion protein. The HER2-specific localization of the $\alpha$ GalCer/sCD1d-anti-HER2 protein was confirmed by a bio-distribution experiment with ${ }^{125}$ I-labeled $\alpha$ GalCer/sCD1d proteins (Figure 8C). Two groups of mice were injected i.v. with either the $\alpha$ GalCer/sCD1d-anti-HER2 or with the $\alpha \mathrm{GalCer} / \mathrm{sCD} 1 \mathrm{~d}$ protein. Twenty-four hours after i.v. injection of radiolabeled proteins, up to 2 -fold (mean 1.8) more radioactive $\alpha \mathrm{GalCer} / \mathrm{sCD} 1 \mathrm{~d}$-anti-HER2 protein was found in HER2-positive tumors than in HER2-negative ones in mice grafted s.c. with both tumors. In contrast, the $\alpha \mathrm{GalCer} / \mathrm{sCD} 1 \mathrm{~d}$ protein did not localize preferentially in any of the 2 tumors (Figure 8C), and the amount of radioactivity was similar to the background level found in other normal tissues (data not shown).

From all these data obtained in lung and s.c. tumors, we can conclude that the anti-HER2 part of the SCD1d fusion protein allows its specific tumor localization and leads to the accumulation of proliferating iNKT cells at the tumor site followed by the local transactivation of NK and T cells.

\section{Discussion}

The present data reveal that $\alpha$ GalCer-loaded recombinant CD1d complexes induce a sustained activation of iNKT cells associ- ated with the production of the proinflammatory cytokine IFN $\gamma$. Most importantly, when targeted to the tumor site by the genetic fusion of an anti-HER2 scFv antibody fragment to the carboxy terminus of sCD1d, delayed systemic treatment of mice allowed a potent inhibition of lung tumor nodules as well as of established s.c. tumors, induced by the i.v. and s.c. injection of HER2-expressing B16 melanoma cells, respectively. The antitumor effect was associated with the HER2-specific tumor localization of the $\alpha$ GalCer/sCD1d-anti-HER2 fusion protein and with an increased frequency of proliferating iNKT, NK, and $T$ cells at the tumor site. Several comments can be made on these innovative results.

$\alpha$ GalCer is a high affinity ligand for CD1d and a potent activator of iNKT cells, leading to the fast release of TH1 and TH2 cytokines $(9,10)$. So far, $\alpha$ GalCer has been tested in vivo as a free drug or pulsed on DCs. Here we show that a soluble monomeric form of CD1d loaded with $\alpha$ GalCer can fully activate mouse iNKT cells in vivo and that this activation is due to the complex per se and not to the in vivo release of $\alpha \mathrm{GalCer}$. These results support the view that coreceptors such as CD4, CD8, or CD28 are not necessary for the full activation of iNKT cells (36), as it is the case for conventional $\mathrm{T}$ cells. The question remains whether the iNKT activation by soluble $\alpha \mathrm{GalCer} / \mathrm{sCD} 1 \mathrm{~d}$ is peculiar to the high avidity of the $\alpha$ GalCer/CD1d complex for the semi-invTCR and would not occur with a more physiological CD1d ligand, or whether this is due to a property inherent to iNKT cells. Importantly, the recombinant $\alpha$ GalCer-loaded sCD1d molecules described here not only activate iNKT cells but also keep them responsive to repeated injections, in contrast to $\alpha \mathrm{GalCer}$ alone. It is known that the potent effect of free $\alpha$ GalCer is short-lived and is followed by a long-term anergy of iNKT cells $(20,21)$, and that even when surface expression of the invTCR is restored, iNKT cells fail to proliferate and produce IFN $\gamma$ upon $\alpha$ GalCer restimulation (21). So far, the most promising results have been obtained with the administration, in mice and in human subjects, of autologous $\alpha$ GalCer-pulsed DCs instead of free $\alpha$ GalCer $(17,19,20,22,23)$. This strategy showed more prolonged iNKT cell activation, marked by a large expansion in IFN $\gamma$-producing iNKT cells as well as higher numbers of NK, T, and B cells. In this context, it was shown that the type of APC, rather than the dose of $\alpha \mathrm{GalCer}$, might be critical for the continued responsiveness of iNKT cells (21). Indeed, the authors demonstrated that the in vivo transfer of $\alpha \mathrm{GalCer}-$ loaded DCs kept iNKT cells responsive, while transfer of $\alpha$ GalCer-loaded B cells led to the iNKT anergy. However, the in vivo transfer of $\alpha$ GalCer-loaded DCs applied to the clinic involves sampling of autologous blood cells followed by their reinjection in the patient after in vitro treatment, representing a relatively invasive and costly procedure. Here we propose a noninvasive strategy to induce sustained iNKT cell activation and exploit its unique capacity to transactivate effector cells from the innate and adaptive immune system. We show that recombinant 
A
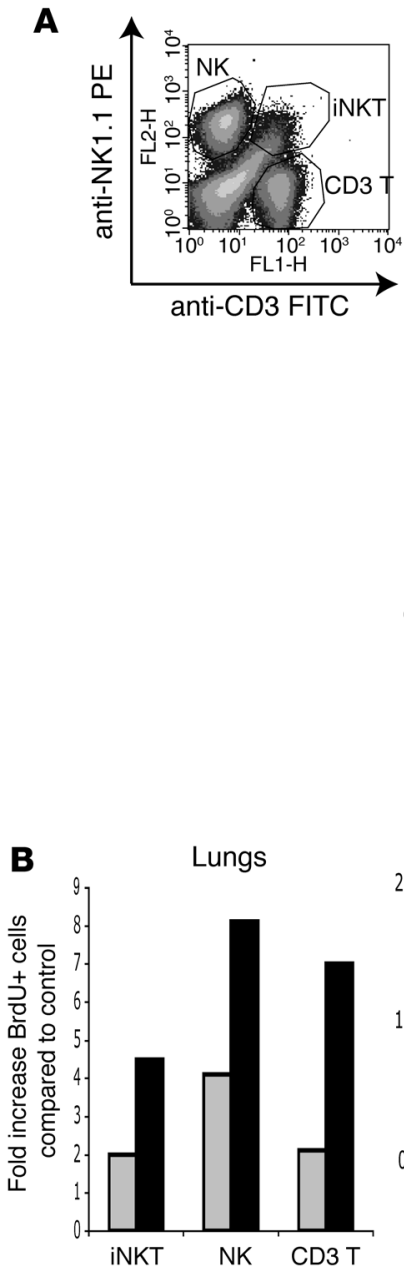
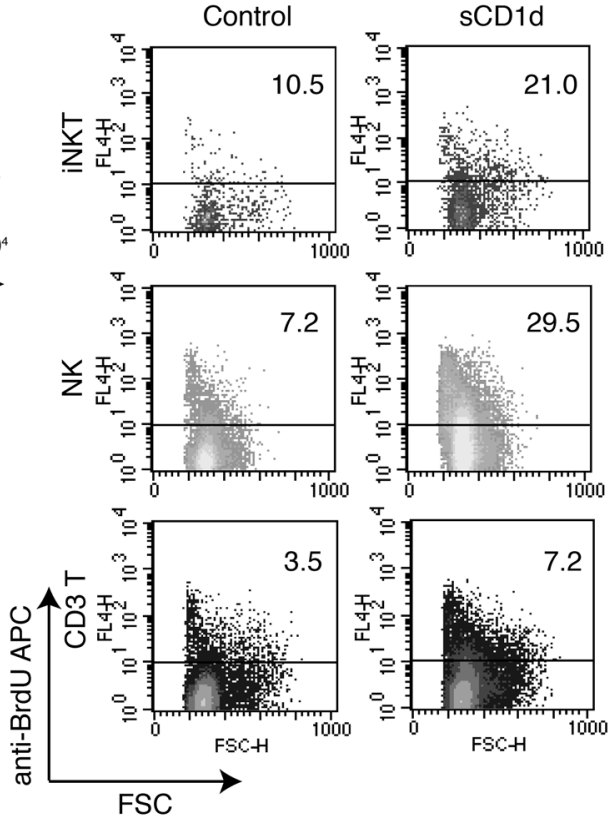

FSC
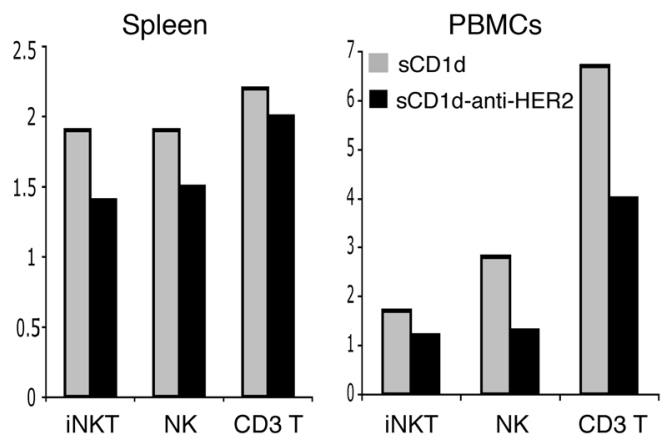
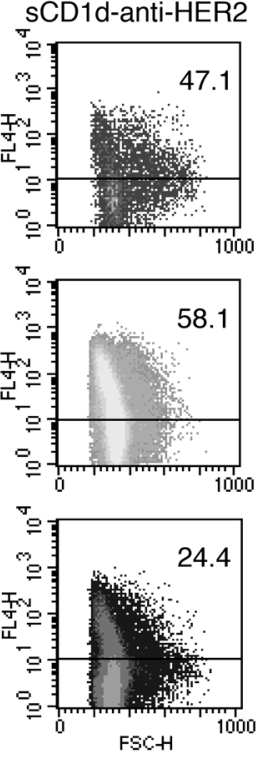

Figure 8

The $\alpha$ GalCer/sCD1d-anti-HER2 fusion protein redirects iNKT, NK, and T cells to HER2-expressing lung tumors and specifically localizes at the tumor site. To study tumor targeting, mice were grafted with 700,000 B16-HER2 cells i.v., and systemic treatment, as described in Figure 4 , was started 10 days after the tumor graft. For BrdU-incorporation, mice were injected i.p. with $1 \mathrm{mg}$ BrdU on day 10, and BrdU was added to the drinking water throughout the whole experiment. Two days after the third injection, mice were sacrificed, lymphocytes were isolated from lungs, spleen, and PBMCs and stained with anti-NK1.1-PE, anti-CD3-FITC, and anti-BrdU-APC. Proliferation of iNKT, NK, and CD3 T cells is shown as percent of BrdU-positive cells in the respective population. (A) Dot plots with numbers indicating the percent of BrdU-positive iNKT, NK, and T cells isolated from lung tissue and (B) graphs of BrdU-incorporation in iNKT, NK, and CD3 T cells from lungs, spleen, and PBMC expressed as fold increase of BrdU-positive cells compared with control group. (C) Biodistribution study with radiolabeled sCD1d molecules. Mice were grafted s.c. on each flank with $1 \times 10^{6}$ of either B16-HER2 or B16 wt cells. On day 8, 2 groups of mice were injected with equimolar amounts of either ${ }^{125}$-labeled $\alpha$ GalCer/sCD1d or $\alpha$ GalCer/sCD1d-anti-HER2. Twenty-four hours later, mice were sacrificed and radioactivity was measured in tumors and normal tissues. Results are expressed as percent of injected dose per gram of tissue. Mean \pm SD of 3 mice per group. * $P<0.05$ for $\alpha$ GalCer/sCD1d-anti-HER2 in B16-HER2 tumors versus B16 wt tumors; ** $P<0.02$ for $\alpha$ GalCer/sCD1d-anti-HER2 versus $\alpha$ GalCer/sCD1d in B16-HER2 tumors.

$\alpha \mathrm{GalCer} / \mathrm{sCD} 1 \mathrm{~d}$ molecules seem to be as potent as $\alpha \mathrm{GalCer-}$ pulsed DCs in keeping iNKT cells responsive upon repeated injections. Liver and spleen iNKT cells were shown to produce IFN $\gamma$, after multiple i.v. injections and upon in vitro restimulation with the $\alpha$ GalCer-loaded sCD1d proteins, while no significant IL-4 could be detected. Moreover, up to a 10 -fold increased percentage of iNKT cells could be transiently detected in the blood 3-4 days after each injection of the 2 forms of $\alpha \mathrm{GalCer} / \mathrm{sCD} 1 \mathrm{~d}$ proteins, while iNKT cells remained undetectable in $\alpha$ GalCer-treated mice. The increased frequency of iNKT cells was confirmed in spleen, liver, and lungs and was associated with BrdU incorporation, dem- onstrating that iNKT cells actively proliferated upon injections of $\alpha \mathrm{GalCer} / \mathrm{sCD} 1 \mathrm{~d}$ proteins.

Regarding the immunoregulatory role of iNKT cells, several studies have reported a powerful influence of $\alpha$ GalCer-activated iNKT cells in the transactivation of cells involved in the innate and adaptive immune response $(31-33,37)$. Thus, free $\alpha$ GalCer or $\alpha$ GalCer-pulsed DCs have been considered as possible adjuvants $(17,22,33,35,37)$. Although the exact mechanism of action still needs further investigation, the present data show that iNKT cells activated by recombinant $\alpha$ GalCer/sCD1d complexes retained all the functional characteristics of $i N K T$ cells activated by $\alpha$ GalCer 
presented by professional APCs. Indeed, the activated iNKT cells analyzed here led to NK cell activation, DC maturation, and expansion of conventional $\mathrm{T}$ lymphocytes, suggesting that recombinant $\alpha \mathrm{GalCer} / \mathrm{sCD} 1 \mathrm{~d}$ complexes could represent attractive adjuvants. In this context, other glycolipid ligands could be loaded on such recombinant $\mathrm{CD} 1 \mathrm{~d}$ molecules to study and possibly manipulate the cytokine profile of iNKT cells. In addition to this potent adjuvant effect, the sustained activation of iNKT cells by recombinant CD1d molecules may offer a new model to study the role of these lymphocytes in tumor immunosurveillance, which has been until now mainly addressed by studying V $\alpha 14 \mathrm{~J} \alpha 18+$ TCR chain alpha chain- and CD1d-deficient mice (38).

Importantly, the antitumor activity described in the present study is explained on one hand by the sustained responsiveness of iNKT cells to repeated injections of recombinant $\alpha$ GalCer-loaded sCD1d molecules and on the other hand by the tumor-targeting effect of the $\alpha \mathrm{GalCer} / \mathrm{sCD} 1 \mathrm{~d}$-anti-HER2 fusion protein. Even when treatment was started 6 days after the injection of the HER2expressing B16 melanoma cells, there was still $60 \%$ less metastatic invasion in the $\alpha$ GalCer/sCD1d-anti-HER2 treated mice than in controls or $\alpha$ GalCer-treated animals. Similarly, established s.c. tumors, treated with the $\alpha$ GalCer/sCD1d-anti-HER2 fusion protein 7 days after the graft, were on average $60 \%$ smaller than in controls or $\alpha$ GalCer-treated animals. This growth inhibition obtained in 2 models of established tumors did not occur with the nontargeted form of $\alpha \mathrm{GalCer} / \mathrm{sCD} 1 \mathrm{~d}$ even when coinjected with the tumor cells, indicating the essential role of the antitumor targeting part of the bifunctional molecule.

Previous work from our group has shown that soluble MHC class I molecules refolded with a viral peptide antigen could be targeted to the tumor site by their coupling with an antitumor antibody fragment. Such bifunctional molecules were able to redirect an ongoing antiviral $\mathrm{T}$ cell response against cancer cells in vivo $(25,26)$. Here we developed a similar strategy applied to CD1d fused to the anti-HER2 scFv 4D5 with the aim to redirect iNKT cells to HER2-expressing tumor cells. This high-affinity antibody, scFv, has been derived from the mouse anti-HER $2 \mathrm{mAb}$ 4D5 (27), which is at the origin of the humanized version Herceptin (trastuzumab) used in the clinic (39). The tyrosine kinase receptor HER2 is overexpressed in 25\%-30\% of human breast cancers, primary tumors, and metastatic sites, and this parameter is associated with poor prognosis. The high-affinity anti-HER $2 \mathrm{mAb}$ Herceptin is now usually administered in breast cancer patients in combination with chemotherapy, providing an overall survival advantage (39). Although the exact mechanisms of how the antiHER $2 \mathrm{mAb}$ exerts its antitumor activity are not clear, it appears to be an excellent tool to target HER2-expressing cancer cells. In the present study, the anti-HER2 part of the CD1d fusion protein was able to redirect activated iNKT cells to the tumor site, while the intact murine anti-HER $2 \mathrm{mAb}$ alone had no effect. In view of the present results, the targeting of CD1d molecules to the tumor via an anti-HER2 antibody fragment appears promising for the treatment of tumor metastases such as those occurring in breast carcinoma or other cancer overexpressing HER2. Moreover, highaffinity antibody fragments specific for various tumor-associated antigens, such as CEA (reviewed in ref. 40), could be fused to target CD1d to additional types of cancers.

The described accumulation of proliferating iNKT, NK, and T cells in lungs invaded by HER2-expressing tumors suggest that the 3 cell types may participate in the antitumor activity. With regard to NK cells, their depletion indeed confirmed that the antitumor activity of iNKT cells occurs in large part through the activation of NK cells $(14-16,23)$. In the further evaluation of this strategy, the respective role of each transactivated cell type in the inhibition of tumor development will be dissected, and the antigen specificities of the generated $\mathrm{T}$ lymphocytes as well as their possible protective role upon tumor rechallenge will be studied. The adjuvant effect of recombinant $C D 1 d$ may initiate specific antitumor $T$ cell responses, and antitumor CD1d therapy combined with active antitumor immunization would be very advantageous. There is increasing evidence that the tumor environment develops immunosuppressive mechanisms that considerably limit the success of tumor vaccine strategies (41-44). The acute inflammatory response created by the activation of iNKT and NK cells at the tumor site may help to overcome immunosuppression and favor the cytotoxicity of antitumor specific T cells.

The present results represent a proof of principle of the antibody-mediated delivery at the tumor site of the iNKT-activating molecule CD1d. Since CD1d is a monomorphic MHC class Ilike antigen-presenting molecule, it would represent an global approach to treat a majority of cancer patients. Altogether, this strategy would promote both innate and adaptive immune responses at the tumor site.

\section{Methods}

Mice, cell lines, and antibodies. Female mice C57BL/6, 6-8 weeks old, were purchased from Harlan. CD1 $\mathrm{d}^{-/-}$mice (45) were bred in the animal facility and tested at the same age as wild-type $\mathrm{B} 6$ mice. All animal experiments were conducted under the authorization and with approval of the review board of the Veterinary Service from Canton de Vaud, Lausanne, Switzerland. The B16-F10 melanoma cell line was stably transfected with the human HER2 antigen (cloned in pcDNA3; kind gift from Y. Yarden, Weizmann Institute of Science, Rehovot, Israel), selected with $1.2 \mathrm{mg} / \mathrm{ml} \mathrm{G} 418$, and cloned. Expression of HER2 was monitored by FACS (BD FACScan) with the humanized anti-HER2 monoclonal antibody Herceptin (trastuzumab; Hoffmann-La-Roche) and goat anti-human IgG-FITC (Sigma-Aldrich). All other antibodies, unless specified, were from Becton Dickinson (BD Biosciences). The software used was CellQuest (version 3.3; BD Biosciences).

Construction of soluble $\beta_{2} m-C D 1 d$ and $\beta_{2} m-C D 1 d-4 D 5$ scFv fusion proteins. Mouse $\beta_{2} \mathrm{~m}$ and sCD1d were cloned by PCR. Total RNA was extracted from the CD1d-transfected mouse RMA.S cell line using the RNeasy Mini Kit (QIAGEN). For the anti-HER2 antibody part, the plasmid pIG6-4D5, containing the $\mathrm{scFv}$ fragment derived from the mouse anti-HER2 antibody 4D5, was used as template (27) (kind gift from A. Pluckthun, University of Zurich, Zurich, Switzerland). Briefly, the entire mouse $\beta_{2}$ m was amplified with a Hind III site at the $\mathrm{N}$-terminus for subsequent cloning in the PEAK 8 expression vector (EdgeBioSystems) and an Nhe I site at its C-terminus for its ligation to the $\mathrm{N}$-terminal sequence of the a1 domain of CD1d, with the insertion of a sequence encoding a flexible glycine/serine-rich peptide linker (GGGGSGGSGSGGG). The primers used for this PCR were 5'TTAAGCTTATGGCTCGCTCGGTGA and 5'-AAGATATCGCTAGCTCCACCTCCAGAACCGGATCCACCTGATCCACCTCCACCCATGTCTCGATCCCAGTAGA (restriction sites are underlined). The C-terminus of the sCD1d fragment was either directly fused to a $6 \mathrm{xHis}$ tag via a small linker (SSGSGG) (for soluble $\beta_{2} \mathrm{~m}$-CD1d) or ligated to the $\mathrm{N}$-terminus of the 4D5 scFv fragment via the same flexible linker as above (GGGGSGGSGSGGG) and a Nar I restriction site (for the CD1d-4D5 fusion). The primers for this PCR were 5 -TTCTCGAGGCTAGCCAGCAAAAGAATTACACCTTC (sense) and 5'-TTGAATTCGGCGCCTCCACCTCCAGAACCGGATCCACCTGATCCACCTCCACCGCCCACGGGTGCTTGCCTGGCAT 
(reverse). The DNA fragment for the anti-HER2 4D5 scFv was fused at the C-terminus to the small glycine/serine-rich linker (SSGSGG) followed by the $6 \mathrm{xHis}$ tag, a stop codon, and a Not I site for subcloning. The PCR primers were 5 '-TTCTCGAGGGCGCCGACTACAAAGATATCGTTAT (sense) and 5'-AAGCGGCCGCTTAATGGTGGTGATGATGATGTCCTCCAGAACCAGAAGAAACGGTAACGGTGGTA (reverse). PCR was performed using Pwo Polymerase (Roche), and amplified DNA fragments were cloned into PCR-Blunt vector (Invitrogen) and sequenced to ensure no mutation was introduced. Using the described restriction sites, a 2- or 3 -part ligation reaction was performed to join the $\beta_{2} \mathrm{~m}$ and linker to the sCD1d and, in the case of the fusion, to the 4D5 scFv DNA part with concomitant subcloning into the pEAK8 expression vector (EdgeBiosystems).

Recombinant protein production by transient transfection. Plasmid DNA was prepared using the EndoFree Plasmid Giga Kit (QIAGEN), and all cell culture media were chemically defined and free of animal-derived components in order to limit endotoxin contamination. The human cell line HEK293 EBNA was adapted to serum-free suspension growth in Excell-293 medium (SAFC Biosciences) in 1-1 glass bottles placed on an orbital shaker (Kühner AG). For large scale transfection in suspension cultures, cells were seeded in serum-free RPMI medium (with 25 mM HEPES; Lonza) at a density of $2 \times 10^{6} \mathrm{cells} / \mathrm{ml}$, and transfected using linear $25-\mathrm{kD}$ polyethyleneimine, as described in ref. 28. Four hours after transfection, the culture was diluted by adding 1 volume of Pro-293s medium (Lonza). After 6 days, the culture was centrifuged, and the supernatant was saved for protein purification.

Affinity purification of recombinant proteins and $\alpha$ GalCer loading on CD1d. The His-tagged soluble sCD1d and the sCD1d-anti-HER2 fusion proteins were purified from the HEK293 supernatants using Ni-NTA resin batchwise (Ni-NTA Superflow; QIAGEN), and bound proteins were eluted with $0.25 \mathrm{M}$ Imidazole. Depending on the batch, the yield could reach up to $10 \mathrm{mg} / 1$ supernatant of pure soluble or anti-HER2-CD1d fusion proteins. After purification, CD1d was loaded overnight at room temperature with a 3-fold molar excess of $\alpha$ GalCer, and the unbound glycolipid was removed by FPLC (Superdex 200 or Sephacryl S100; Pharmacia Biotech). Recombinant proteins were checked for the level of endotoxin (Apotech Corp.; LAL assay), which was found to be less than $0.5 \mathrm{EU} / \mu \mathrm{g}$ protein corresponding to less than 0.04 ng endotoxin.

Generation of CD1d tetramer. For this purpose, the soluble $\beta_{2} \mathrm{~m}-\mathrm{sCD} 1 \mathrm{~d}$ molecule was modified at the $\mathrm{C}$-terminus by the addition of a cysteine after the stretch of histidine residues. The purified recombinant protein was biotinylated on the cysteine residue by the chemical coupling of a biotin-maleimide linker (EZ-linked BM; Pierce) in 2-molar excess overnight at $20^{\circ} \mathrm{C}$. The excess of linker was removed by gel filtration on a Superdex S200 column (Pharmacia Biotech). The biotinylated CD1d was loaded with $\alpha G a l C e r$ as described above and was tetramerized on Extravidin-PE (SigmaAldrich). Resulting complex was used at $5 \mu \mathrm{g} / \mathrm{ml}$ for iNKT cell staining.

Quantification of lung metastasis. The measure of metastatic nodule surface was performed on $2560 \times 1920$ pixel photographs of the whole organs, taken at a magnification of $\times 6.3$ on a Zeiss Stemi SV11 dissection microscope (Carl Zeiss) equipped with a ProgRes-C10plus Color Camera (Jenoptik). Each image was analyzed with ImageJ (http://rsb.info.nih.gov/ij/) using a k-means clustering algorithm (plug-in available on http://ij-plugins. sourceforge.net). Images were segmented into 9 segments representing different levels of pigmentation (parameter details: cluster tolerance, $1 \times 10^{-4}$; randomization seed, 48). The appropriate segments were selected based on the color of the metastasis reaching the surface of the organ. The area of the sum of selected color segments was expressed as percentage of the area occupied by the lungs. Both sides of the lung were analyzed.

Precoating of tumor cells with CD1d complexes. B16-HER2 or B16 wild-type tumor cells $\left(6 \times 10^{6}\right.$ in $\left.500 \mu \mathrm{l}\right)$ were preincubated for 1 hour on ice either with $40 \mu \mathrm{g} / \mathrm{ml} \alpha \mathrm{GalCer} / \mathrm{sCD} 1 \mathrm{~d}$-anti-HER2 fusion protein, equivalent molar amount of $\alpha \mathrm{GalCer}$ alone $(0.4 \mu \mathrm{g} / \mathrm{ml})$, the anti-HER $2 \mathrm{mAb}$ Herceptin $(10 \mu \mathrm{g} / \mathrm{ml})$, or nothing. Excess of unbound fusion or antibody was washed away unless specified. Tumor cells were injected i.v. (700,000 cells in $300 \mu \mathrm{l} \mathrm{PBS}$ ), and on day 20 mice were sacrificed and the lung metastatic surface was quantified.

Systemic treatment. Groups of 5-8 mice were grafted i.v. or s.c. with 700,000 B16-HER2 or B16 wild-type cells. At specified time points, they were treated i.v. with $200 \mu \mathrm{l}$ of either PBS alone, equimolar amounts of $\alpha$ GalCer $(0.4 \mu \mathrm{g}), \alpha \mathrm{GalCer} / \mathrm{sCD} 1 \mathrm{~d}$-anti HER2 fusion $(40 \mu \mathrm{g})$, or $\alpha \mathrm{GalCer} / \mathrm{sCD} 1 \mathrm{~d}$ $(25 \mu \mathrm{g})$. Treatment was repeated i.v. at 3- to 4-day intervals, as specified. After 3 weeks, mice were sacrificed, and the percentage of lung surface invaded by metastatic nodules was quantified. S.c. tumor growth was monitored every 2 days by measuring the 3 orthogonal diameters with a caliper and using the following formula: (length $\times$ width $\times$ thickness) $/ 2$.

$N K$ cell depletion. NK cells were specifically depleted by the repeated i.p. injections of $60 \mu \mathrm{l}$ of anti-asialo-GM1 (Wako Pure Chemicals). The first injection was done 1 day before starting the antitumor treatment and repeated every other day for a total of 3 injections.

Isolation of liver, lung, and spleen lymphocytes. Mouse livers and lungs were homogenized with a $100 \mu \mathrm{m}$ strainer, and lymphocytes were isolated using a Percoll density gradient (Amersham Biosciences). After 2 washings, cells were either rechallenged or directly analyzed by fluorescence cytometry. Spleens were homogenized with a $70 \mu \mathrm{m}$ strainer, debris were eliminated by spontaneous sedimentation, and splenocytes were recovered by centrifugation.

In vitro iNKT rechallenge. Liver, lung, and spleen lymphocytes $\left(2 \times 10^{6} / \mathrm{ml}\right)$ were activated by either $200 \mathrm{ng} / \mathrm{ml} \alpha$ GalCer or by $\alpha$ GalCer/sCD1d-antiHER2 fusion protein $(10 \mu \mathrm{g} / \mathrm{ml})$ bound to plastic-coated anti-His mAb. As positive control, cells were stimulated with phorbol ester and ionomycin at $50 \mathrm{ng} / \mathrm{ml}$ and $1 \mu \mathrm{g} / \mathrm{ml}$, respectively. Golgi Plug (BD) was added after 1 hour, and after a total of 6 hours incubation, activated lymphocytes were stained with different antibody combinations to gate on iNKT cells. AntiCD3-FITC was generally tested with $\alpha$ GalCer/sCD1d tetramer-PE or, in case of iNKT invTCR downmodulation, with NK1.1-PE. After fixation and permeabilization with Cytofix/Cytoperm (BD), intracellular IFN $\gamma$ was detected with an APC-labeled anti-IFN $\gamma$ monoclonal antibody. Cells were analyzed on a FACSCalibur (BD).

$D C$ preparation from spleen. Spleens were disrupted by an initial incubation with collagenase $\mathrm{D}, 20 \mathrm{~min}$ at $37^{\circ} \mathrm{C}$ (Roche Diagnostics Corp.), followed by homogenization on a $70 \mu \mathrm{m}$ cell strainer. DC cell population was sorted by using anti-CD11c-coated magnetic beads and LS columns, as recommended by the manufacturer (Miltenyi Biotech). FACS analysis was performed on the bound fraction containing at least $80 \%$ DC.

In vivo BrdU incorporation. Mice were grafted with 700,000 B16-HER2 cells i.v., and treatment with either PBS, equimolar amounts of $\alpha \mathrm{GalCer}$, $\alpha \mathrm{GalCer} / \mathrm{sCD} 1 \mathrm{~d}(25 \mu \mathrm{g})$, or $\alpha \mathrm{GalCer} / \mathrm{sCD} 1 \mathrm{~d}$-anti-HER2 proteins $(40 \mu \mathrm{g})$ was started on day 10 after tumor graft. The same day, $1 \mathrm{mg}$ BrdU was given i.p., and BrdU was added to the drinking water throughout the whole experiment. Two days after the third injection, mice were sacrificed, and lymphocytes were isolated from spleen and blood. For the isolation of lymphocytes from lungs, tissue was minced in a solution of Collagenase Type I (Sigma-Aldrich) and DNase I (Roche) and incubated at $37^{\circ} \mathrm{C}$ for $90 \mathrm{~min}$. Digested tissue was passed through a $70 \mu \mathrm{m}$ strainer. Lymphocytes were stained with anti-NK1.1-PE and anti-CD3-FITC. BrdU incorporation was measured by intracellular APC-labeled anti-BrdU according to the manufacturer instructions (APC BrdU Flow Kit; BD). Cells were analyzed on a FACS Calibur (BD).

Radioiodination of $\alpha \mathrm{GalCer} / \mathrm{sCD} 1 \mathrm{~d}$ proteins and in vivo biodistribution. $\alpha$ GalCer/sCD1d and $\alpha$ GalCer/sCD1d-anti-HER2 proteins were labeled with ${ }^{125} \mathrm{I}$ by the iodogen method (Pierce) (46). For biodistribution studies, equimolar amounts of either ${ }^{125} \mathrm{I}-\alpha \mathrm{GalCer} / \mathrm{sCD} 1 \mathrm{~d}(19 \mu \mathrm{g})$ or ${ }^{125} \mathrm{I}-\alpha \mathrm{GalCer} /$ 
sCD1d-anti-HER2 $(30 \mu \mathrm{g})$ proteins were i.v. injected in 2 groups of mice, 8 days after grafting all animals with $1 \times 10^{6} \mathrm{~B} 16$-HER2 cells in the right flank and $1 \times 10^{6} \mathrm{~B} 16-\mathrm{F} 10$ cells in the left flank. For each radiolabeled protein, 3 mice were dissected 24 hours after injection. Organs were weighed, and the radioactivity in all tissue was measured in a gamma counter. The results were expressed as the percentage of the injected dose per gram of tissue.

Statistics. Data are presented as mean \pm SD. Statistical significance between the groups was determined by applying an unpaired 2-tailed Student's $t$ test. A $P$ value lower than 0.05 was considered as statistically significant.

\section{Acknowledgments}

This work was supported by the Swiss Cancer League (Oncosuisse grant OCS-01407-08-2003; to K. Stirnemann), the Swiss National
Science Foundation (to H.R. MacDonald), and Vaccinex Inc., Rochester, New York, US. G.S. Besra acknowledges support in the form of a Personal Research Chair from James Bardrick, as a former Lister Institute-Jenner Research Fellow, and from the Medical Research Council (UK) and The Wellcome Trust.

Received for publication July 11, 2007, and accepted in revised form December 12, 2007.

Address correspondence to: Alena Donda, Department of Biochemistry, University of Lausanne, Chemin des Boveresses 155, CH-1066 Epalinges, Switzerland. Phone: 41-21-692-5737; Fax: 4121-692-5705; E-mail: alena.donda@unil.ch.
1. de Visser, K.E., Eichten, A., and Coussens, L.M. 2006. Paradoxical roles of the immune system during cancer development. Nat. Rev. Cancer. 6:24-37.

2. Dunn, G.P., Old, L.J., and Schreiber, R.D. 2004. The immunobiology of cancer immunosurveillance and immunoediting. Immunity. 21:137-148.

3. Boon, T., et al. 2006. Human T cell responses against melanoma. Annu. Rev. Immunol. 24:175-208.

4. Michaeli, D. 2005. Vaccines and monoclonal antibodies. Semin. Oncol. 32:S82-S86.

5. Bendelac, A., et al. 1997. Mouse CD1-specific NK1 $\mathrm{T}$ cells: development, specificity, and function. Annu. Rev. Immunol. 15:535-562.

6. Exley, M., et al. 1997. Requirements for CD1d recognition by human invariant Valpha24+ CD4CD8- T cells. J. Exp. Med. 186:109-120.

7. Zhou, D., et al. 2004. Lysosomal glycosphingolipid recognition by NKT cells. Science. 306:1786-1789.

8. Mattner, J., et al. 2005. Exogenous and endogenous glycolipid antigens activate NKT cells during microbial infections. Nature. 434:525-529.

9. Yoshimoto, T., and Paul, W.E. 1994. CD4pos, NK1.1pos T cells promptly produce interleukin 4 in response to in vivo challenge with anti-CD3. J. Exp. Med. 179:1285-1295.

10. Matsuda, J.L., et al. 2000. Tracking the response of natural killer $\mathrm{T}$ cells to a glycolipid antigen using CD1d tetramers. J. Exp. Med. 192:741-754.

11. Kronenberg, M. 2005. Toward an understanding of NKT cell biology: progress and paradoxes. Annu. Rev. Immunol. 23:877-900.

12. Crowe, N.Y., et al. 2005. Differential antitumor immunity mediated by NKT cell subsets in vivo. J. Exp. Med. 202:1279-1288.

13. Kawano, T., et al. 1997. CD1d-restricted and TCRmediated activation of valpha14 NKT cells by glycosylceramides. Science. 278:1626-1629.

14. Hayakawa, Y., et al. 2001. Critical contribution of IFN-gamma and NK cells, but not perforin-mediated cytotoxicity, to anti-metastatic effect of alphagalactosylceramide. Eur. J. Immunol. 31:1720-1727.

15. Takeda, K., et al. 2000. Relative contribution of NK and NKT cells to the anti-metastatic activities of IL-12. Int. Immunol. 12:909-914.

16. Smyth, M.J., et al. 2002. Sequential production of interferon-gamma by NK1.1(+) T cells and natural killer cells is essential for the antimetastatic effect of alpha-galactosylceramide. Blood. 99:1259-1266.

17. Nieda, M., et al. 2004. Therapeutic activation of Valpha24+Vbeta11+ NKT cells in human subjects results in highly coordinated secondary activation of acquired and innate immunity. Blood. 103:383-389.

18. Giaccone, G., et al. 2002. A phase I study of the natural killer T-cell ligand alpha-galactosylceramide
(KRN7000) in patients with solid tumors. Clin. Cancer Res. 8:3702-3709.

19. Ishikawa, A., et al. 2005. A phase I study of alphagalactosylceramide (KRN7000)-pulsed dendritic cells in patients with advanced and recurrent non-small cell lung cancer. Clin. Cancer Res. 11:1910-1917.

20. Fujii, S., et al. 2002. Prolonged IFN-gamma-producing NKT response induced with alpha-galactosylceramide-loaded DCs. Nat. Immunol. 3:867-874.

21. Parekh, V.V., et al. 2005. Glycolipid antigen induces long-term natural killer $\mathrm{T}$ cell anergy in mice. J. Clin. Invest. 115:2572-2583.

22. Chang, D.H., et al. 2005. Sustained expansion of NKT cells and antigen-specific T cells after injection of alpha-galactosyl-ceramide loaded mature dendritic cells in cancer patients. J. Exp. Med. 201:1503-1517.

23. Smyth, M.J., et al. 2005. Sequential activation of NKT cells and NK cells provides effective innate immunotherapy of cancer. J. Exp. Med. 201:1973-1985.

24. Im, J.S., et al. 2004. Direct measurement of antigen binding properties of CD1 proteins using fluorescent lipid probes. J. Biol. Chem. 279:299-310.

25. Cesson, V., et al. 2006. Active antiviral T-lymphocyte response can be redirected against tumor cells by antitumor antibody x MHC/viral peptide conjugates. Clin. Cancer Res. 12:7422-7430.

26. Donda, A., et al. 2003. In vivo targeting of an antitumor antibody coupled to antigenic MHC class I complexes induces specific growth inhibition and regression of established syngeneic tumor grafts. Cancer Immun. 3:11.

27. Worn, A., and Pluckthun, A. 1998. An intrinsically stable antibody scFv fragment can tolerate the loss of both disulfide bonds and fold correctly. FEBS Lett. 427:357-361.

28. Baldi, L., et al. 2005. Transient gene expression in suspension HEK-293 cells: application to large-scale protein production. Biotechnol. Prog. 21:148-153.

29. Harada, M., et al. 2004. Down-regulation of the invariant Valpha14 antigen receptor in NKT cells upon activation. Int. Immunol. 16:241-247.

30. Elvin, P., and Evans, C.W. 1984. Cell adhesion and experimental metastasis: a study using the B16 malignant melanoma model system. Eur. J. Cancer Clin. Oncol. 20:107-114.

31. Carnaud, C., et al. 1999. Cutting edge: Crosstalk between cells of the innate immune system: NKT cells rapidly activate NK cells. J. Immunol. 163:4647-4650.

32. Eberl, G., Brawand, P., and MacDonald, H.R. 2000. Selective bystander proliferation of memory CD4+ and CD8+ T cells upon NK T or T cell activation.
J. Immunol. 165:4305-4311.

33. Hermans, I.F., et al. 2003. NKT cells enhance CD4+ and CD8 $+\mathrm{T}$ cell responses to soluble antigen in vivo through direct interaction with dendritic cells. J. Immunol. 171:5140-5147.

34. Fujii, S., et al. 2004. The linkage of innate to adaptive immunity via maturing dendritic cells in vivo requires CD40 ligation in addition to antigen presentation and CD80/86 costimulation. J. Exp. Med. 199:1607-1618

35. Silk, J.D., et al. 2004. Utilizing the adjuvant properties of CD1d-dependent NK T cells in T cell-mediated immunotherapy. J. Clin. Invest. 114:1800-1811.

36. Uldrich, A.P., et al. 2005. NKT cell stimulation with glycolipid antigen in vivo: costimulation-dependent expansion, Bim-dependent contraction, and hyporesponsiveness to further antigenic challenge. J. Immunol. 175:3092-3101.

37. Fujii, S., et al. 2003. Activation of natural killer T cells by alpha-galactosylceramide rapidly induces the full maturation of dendritic cells in vivo and thereby acts as an adjuvant for combined CD4 and CD8 T cell immunity to a coadministered protein. J. Exp. Med. 198:267-279.

38. Terabe, M., et al. 2005. A nonclassical non-Valpha14Jalpha18 CD1d-restricted (type II) NKT cell is sufficient for down-regulation of tumor immunosurveillance. J. Exp. Med. 202:1627-1633.

39. Romond, E.H., et al. 2005. Trastuzumab plus adjuvant chemotherapy for operable HER2-positive breast cancer. N. Engl. J. Med. 353:1673-1684.

40. Mach, J.P. 2002. Targeting of monoclonal antibodies for imaging and potential for therapy. In Encyclopedia of life sciences. Nature Publishing Group. London, United Kingdom. 1-13.

41. Pure, E., Allison, J.P., and Schreiber, R.D. 2005. Breaking down the barriers to cancer immunotherapy. Nat. Immunol. 6:1207-1210.

42. Vieweg, J., et al. 2007. Reversal of tumor-mediated immunosuppression. Clin. Cancer Res. 13:727s-732s.

43. Wang, H.Y., and Wang, R.F. 2007. Regulatory T cells and cancer. Curr. Opin. Immunol. 19:217-223.

44. Appay, V., et al. 2006. New generation vaccine induces effective melanoma-specific CD8+ T cells in the circulation but not in the tumor site. J. Immunol. 177:1670-1678.

45. Smiley, S.T., Kaplan, M.H., and Grusby, M.J. 1997. Immunoglobulin $\mathrm{E}$ production in the absence of interleukin-4-secreting CD1-dependent cells. Science. 275:977-979.

46. Robert, B., et al. 1996. Cytokine targeting in tumors using a bispecific antibody directed against carcinoembryonic antigen and tumor necrosis factor alpha. Cancer Res. 56:4758-4765. 